\title{
VÝSKUM TRETEJ (PÔVODNE HORNEJ) BRÁNY HRADU ČABRAĎ V ROKOCH 2013-2015
}

\author{
JÁN BELJAK - PAVOL MALINIAK - MAXIM MORDOVIN - MICHAL ŠIMKOVIC
}

\begin{abstract}
Abstrakt: Výskum tretej brány priniesol poznatky k stavebnému vývoju hradu a jeho podobe v 16. storočí. Je jednou z klúčových stavieb renesančného opevnenia hradu Čabrad'. Po roku 1549 došlo $k$ rozsiahlej obnove hradu spojenej s vybudovaním novej bránovej budovy. Účastou talianskeho stavitel'a Francesca de Pozzo je možné vysvetlit' vyspelú architektúru brány. Obytné priestory v hornom podlaži brány spomínajú písomné pramene zo 16. a 17. storočia. Potvrdzujú ich aj výskumom ziskané archeologické nálezy. Medzi nimi sú tu zastúpené predovšetkým luxusné druhy keramiky. Reprezentujú ich napríklad bohato zdobené misy a taniere, ale aj rôzne tvary habánskej keramiky. Je tu tiež zastúpená kvalitná keramika vyrobená z bielych ílov z územia Gemeru a Novohradu. K vzácnejšim nálezom patria strieborné pracky, zlatý drôtik a bronzové prstene, pútnické a obchodné známky. Takéto nálezy dokladajú dial'kové kontakty majitelov hradu v závere stredoveku. Objavili sme aj numizmatické nálezy, ktoré napomohli spresnit' chronológiu keramiky $v$ tomto regióne.
\end{abstract}

Kl'účové slová: hrad Čabrad' - tretia brána - región Hont - 16. storočie - novoveká keramika - stavebný vývoj - rod Koháry - archeologický výskum - písomné pramene - architektúra.

\section{Research into the Third (Originally the Upper) Gate of Čabrad' Castle in 2013-2015}

\begin{abstract}
Research into the third gate brought information about the building development of the castle and its form in the 16th century. The gate is one of the key constructions of the renaissance fortification of Čabrad' Castle. After 1549 the castle underwent a major renovation connected with the building of a new gate structure. The sophisticated architecture of the gate stems from the involvement of the Italian builder Francesco de Pozzo. Residential quarters on the top floor of the gate construction are mentioned in written sources from the 16th and 17th centuries, and are also confirmed by archaeological finds. These mostly include luxury ceramics such as richly decorated bowls and plates, as well as various shapes of Anabaptist pottery. The finds also comprise quality ceramics made of white clay from the Gemer and Novohrad regions. The most precious among them are silver buckles, a gold wire and bronze rings, pilgrim and trade marks. These items evidence the contacts of the castle owners in the late Middle Ages. There were also numismatic finds that helped specify the chronology of pottery in the region.
\end{abstract}

Key words: Čabrad' Castle - third gate - Hont region - 16th century - modern-age ceramics - building development - Koháry family - archaeological research-written sources - architecture.

\section{Poloha hradu}

Hrad Čabrad' sa nachádza 15 km južne od Krupiny, v južnej časti Krupinskej planiny na strednom Slovensku. Je situovaný na výbežku vrchu Táborisko v nadmorskej výške $324 \mathrm{~m}$ n. m. Hradný vrch je položený v meandri rieky Litava, pričom ho prevyšuje okolitá planina. Z dial'kových pohl'adov je preto málo dominantný. $Z$ doliny Litavy je hrad dobre viditel'ný iba z miesta zaniknutej osady Čabrad' (pôvodne Čabradské Podhradie). Údolím Litavy priamo popod hrad viedla trasa historickej dial'kovej cesty smerujúcej z južnej časti Hontu do Zvolena (obr. 1).

Hradný komplex je trojdielny. Tvorí ho hradné jadro a okolo neho rozložené štyri predhradia. Hradné jadro na vrchole brala má takmer pravidelný obdížnikový pôdorys (obr. 2). Jeho ústrednou stavbou je hranolová obytná veža (obr. 3:1), ku ktorej sa na severnej strane pripája nádvorie obstavané obytnými krídlami (obr. 3:2). K hradnému jadru je na čelnej južnej strane pripojený polygonálny bastión, chrániaci prístup k hornému hradu (obr. 3:3). Na protil’ahlej severnej strane je k jadru pristavané prvé predhradie s pravidelným obdĺžnikovým pôdorysom, ktorého opevnenie zosilňuje hranolová bašta (obr. 3:5). Na severnej strane predhradia bolo úzke obytné krídlo (obr. 3:6), prepojené s hradným jadrom zaklenutou arkádovou chodbou (obr. 3:7). Z vonkajšej strany je k opevneniu predhradia pristavaná mohutná bránová budova (obr. 3:4). Zo severnej strany je k prvému predhradiu pripojený opevnený areál s dvoma baštami v nárožiach 
na severnej strane (obr. 3:8). Komplex hornej časti hradu obklopuje opevnenie druhého predhradia, uzatvárajúce rozšírený priestor na južnom úpätí hradného jadra. Na východnej strane opevnenia predhradia sú dve obranné bašty (obr. 3:13, 14). V exponovanej juhozápadnej strane predhradia je budova vstupnej brány krytá dvojicou delostreleckých bastiónov (obr. 3:11, 12). Objektovú skladbu hradu dopíňa malé prechodné predbránie na juhozápadnej strane, vysunuté pred vstupnú bránu (obr. 3:9).

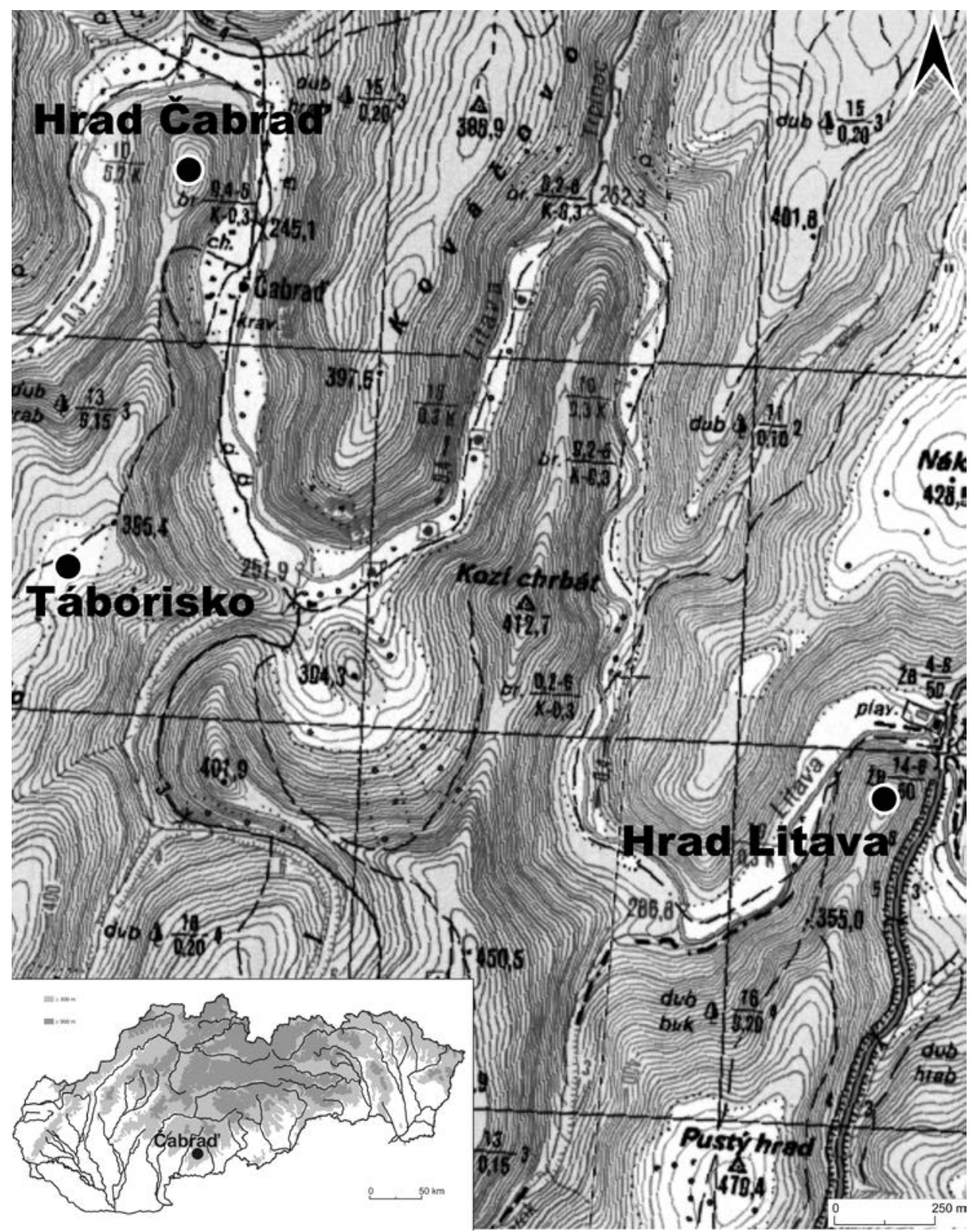

Obr. 1. Situovanie hradu Čabrad' a d'alších fortifikácií v doline riečky Litava.

Abb. 1. Lage von Burg Čabrad' und weiterer Befestigungsanlagen im Flusstal der Litava. 


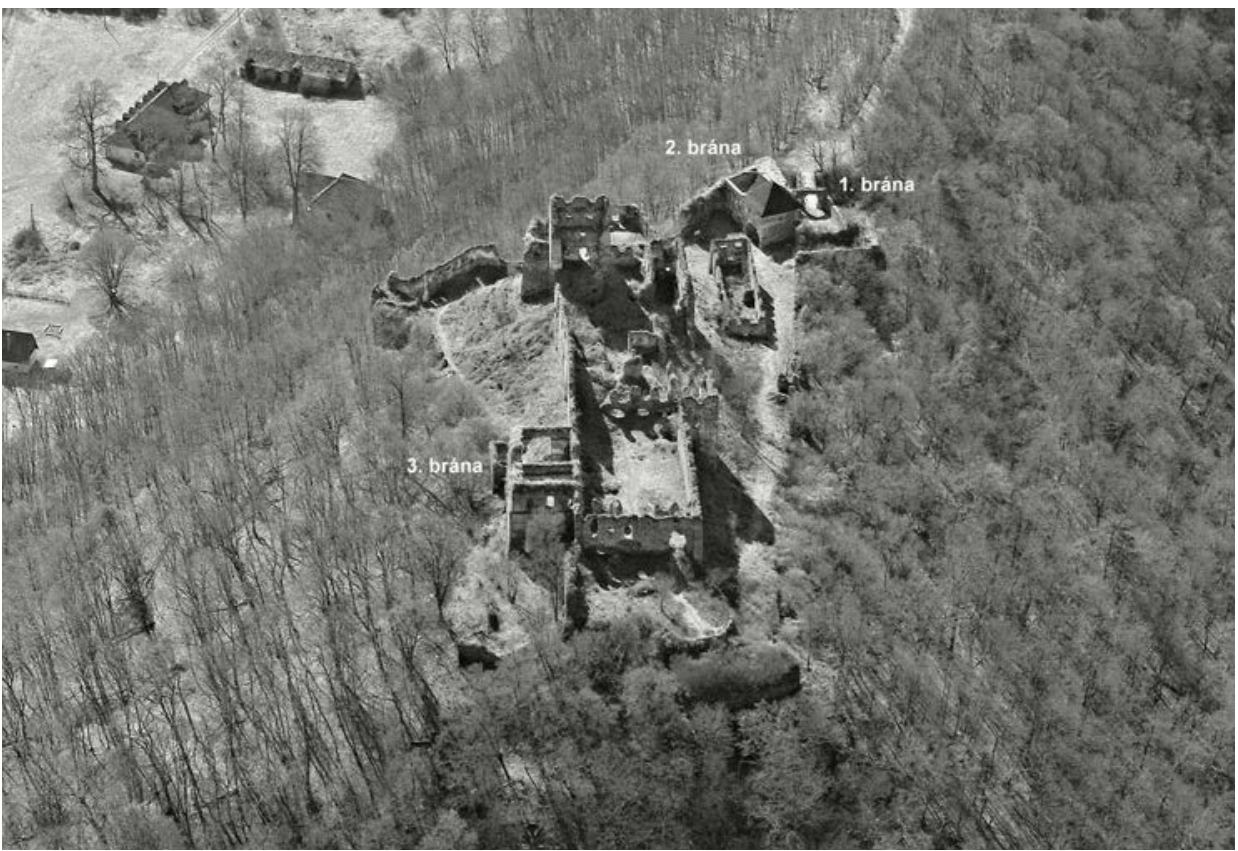

Obr. 2. Hrad Čabrad', okr. Krupina. Letecká snímka z roku 2011. Vyznačené sú hlavné hradné objekty. Foto J. Beljak. Abb. 2. Burg Čabrad', Bezirk Krupina. Luftaufnahme aus dem Jahr 2011. Gekennzeichnet wurden die Hauptobjekte der Burg. Foto J. Beljak.

\section{Dejiny bádania}

Výskum hradu Čabrad' ovplyvňovala v minulosti aj jeho odlahlost', hoci bol živou stavbou až do začiatku 19. storočia (obr. 4). Prvé podrobnejšie poznatky o dejinách hradu s dôrazom na novoveké dejiny a vlastníkov - rod Koháryovcov - uverejnil Kálmán Thaly (1867; 1867a). Prehlad najmä politických udalostí vo vztahu k rodu Koháryovcov a ich sídelným hradom Čabrad’ sledovala aj kapitola v monografii Hontianskej župy (Borovszky b. r., 293, 454). Pravdepodobne prvé presnejšie kresby a plán hradu vyhotovil v roku 1889 J. Könyöki (obr. 9). Na základe vlastného prístupu a dobových kritérií charakteristicky zdokumentoval hrad a jeho jednotlivé objekty (Váliné Pogány 2000, 77-78). Odhliadnuc od pamiatkových výskumov, resp. prieskumov, sa bádanie $\mathrm{v}$ prvých desat'ročiach 20 . storočia dynamicky nerozvíjalo. V povojnovom období pozorujeme kvalitatívny posun výskumu k analýze konkrétnych prameňov. Krátky príspevok o hrade s dôrazom na vybraný dokument z 15. storočia venoval Peter Ratkoš (Ratkoš 1958, 95-96). Na stavebný vývoj sa následne sústredili Hilda a Andrej Fialovci v prvej vel'kej monografii o hradoch na Slovensku (Fialová-Fiala 1966). Tieto informácie boli použité aj v Súpise pamiatok na Slovensku (SPS I, 252). Archívno-historický výskum v nasledujúcich desatročiach priniesol mnohé nové informácie. Stredoveké pramene k dejinám Čabrade systematicky zmapoval najmä István Bakács (1971, 47-48). Moderný archeologický výskum realizoval ako prvý V. Hanuliak v roku 1997 v priestore prístavby druhej brány (2004, 299-308; obr. 6). V roku 1998 pokračoval výskum prvej bašty a vel'kej veže. V roku 1999 prebiehal výskum druhej bašty a geodetické zameranie tejto časti hradu.

Od tohoto času sa v pravidelných intervaloch konali pod vedením A. Loydla z občianskeho združenia Rondel brigády zamerané na spriechodnenie hradu, odstraňovanie náletových krovín a úpravu chodníkov. Združenie postupne zrealizovalo zameranie jednotlivých objektov hradu a jeho nádvoria. V rokoch 2002 a 2003 sanovali druhú bránu s následnou stabilizáciou jej klenby a okien. Podobne zrealizovali stabilizáciu korún murív a celú stavbu zastrešili (Loydl 2012, 3). 


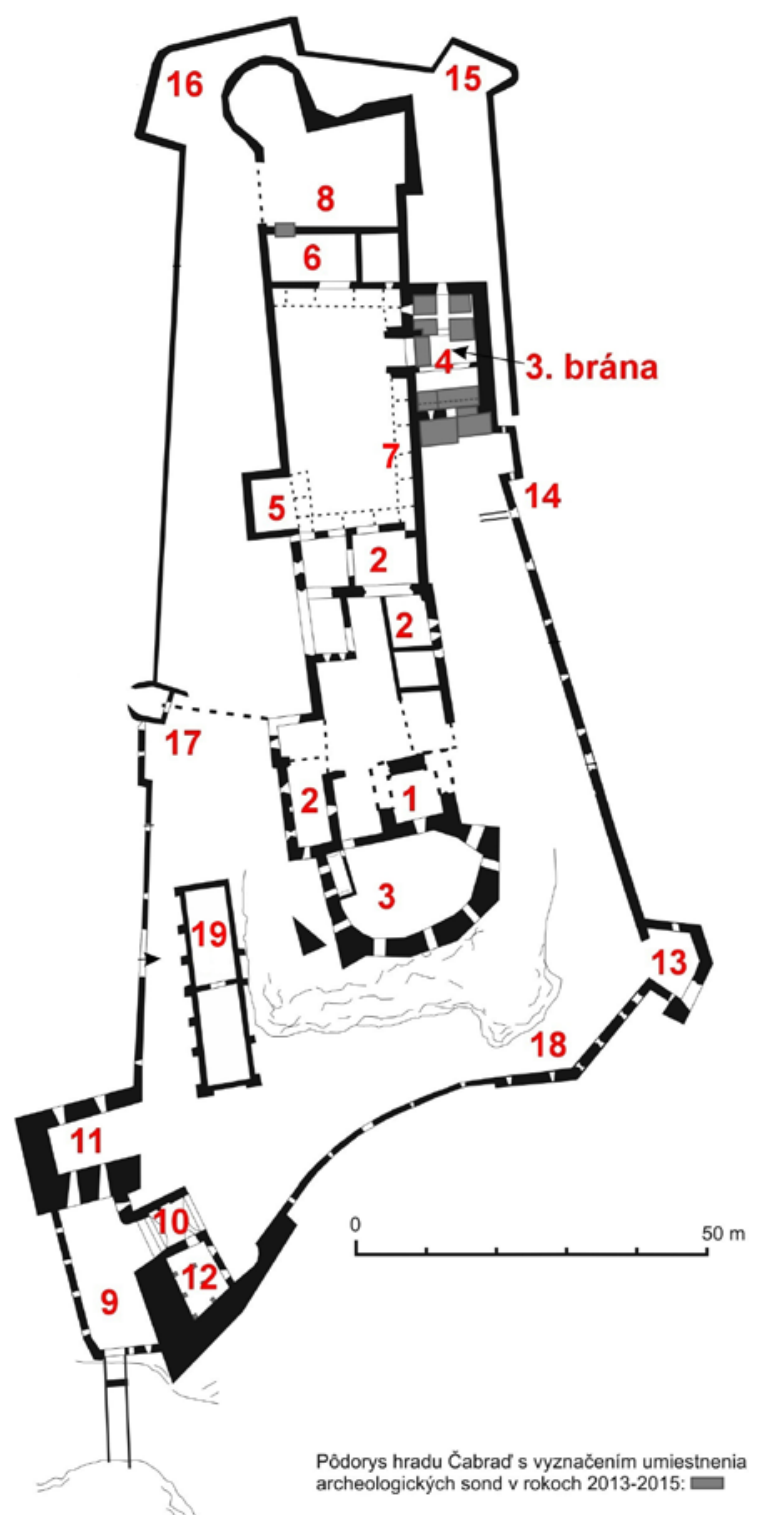

Obr. 3. Hrad Čabrad', okr. Krupina. Pôdorys hradu s vyznačením skúmanej plochy v rokoch 2013-2015. Vyhotovil M. Šimkovic, A. Loydl a J. Beljak. 1 - obytná veža, 2 - palácové stavby jadra, 3 - bastión jadra, 4 -vstupná brána prvého predhradia (tretia brána), 5 - západná bašta prvého predhradia, 6 - palácová stavba prvého predhradia (severný palác), 7 - arkádová chodba okolo nádvoria, 8 - severné opevnenie prvého predhradia s nárožnými baštami, 9 - predbránie druhého predhradia (prvá brána), 10 - brána druhého predhradia (druhá brána), 11 - juhozápadný bastión druhého predhradia, 12 - južný bastión druhého predhradia, 13 - juhovýchodná bašta druhého predhradia, 14 - východná bašta druhého predhradia, 15 - severovýchodná bašta druhého predhradia, 16 - severozápadná bašta druhého predhradia, 17 - západná bašta druhého predhradia, 18 - hospodárska budova a západná bašta druhého predhradia, 19 - sýpka.

Abb. 3. Burg Čabrad', Bezirk Krupina. Grundriss der Burg mit Kennzeichnung der in den Jahren 2013-2015 untersuchten Fläche. Erstellt von M. Šimkovic, A. Loydl und J. Beljak. 1 - Wohnturm, 2 - Palasbau der Kernburg, 3 - Bastei der Kernburg, 4 - Eingangstor der ersten Vorburg (drittes Tor), 5 - Westbastei der ersten Vorburg, 6 - Palasbau der ersten Vorburg (Nordpalas), 7 - Arkadengang um den Burghof, 8 - nördliche Befestigung der ersten Vorburg mit Eckbasteien, 9 - Vortor der zweiten Vorburg (erstes Tor), 10 - Tor der zweiten Vorburg (zweites Tor), 11 - Südwestbastei der zweiten Vorburg, 12 - Südbastei der zweiten Vorburg, 13 - Südostbastei der zweiten Vorburg, 14 - Ostbastei der zweiten Vorburg, 15 - Nordostbastei der zweiten Vorburg, 16 - Nordwestbastei der zweiten Vorburg, 17 - Westbastei der zweiten Vorburg, 18 - Wirtschaftsgebäude und Westbastei der zweiten Vorburg, 19 - Kornspeicher. 


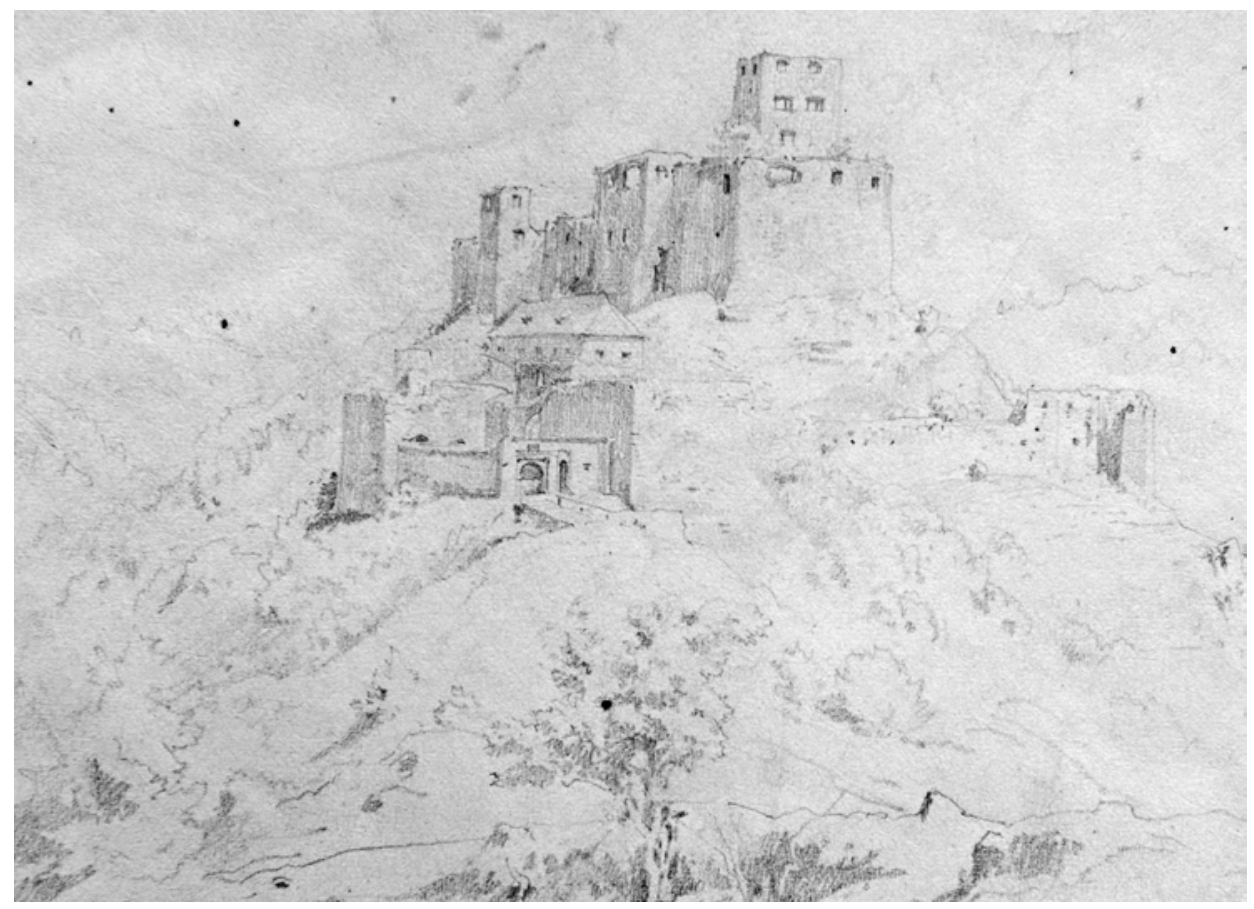

Obr. 4. Hrad Čabrad', okr. Krupina. Kresba zachytávajúca hrad v druhej polovici 19. storočia. Pohl'ad z juhu. Zdroj Forster Gyula Nemzeti Örökségvédelmi és Vagyongazdálkodási Központ.

Abb. 4. Burg Čabrad', Bezirk Krupina. Die Zeichnung stellt die Burg in der ersten Hälfte des 19. dar. Blick von Süden. Quelle Forster Gyula Nemzeti Örökségvédelmi és Vagyongazdálkodási Központ.

V roku 2004 opravili múry v južnej prístavbe druhej brány. V rokoch 2007-2008 strechu museli po zničení vandalmi opätovne opravit'. V tomto roku objavili aj originálnu tehlovú podlahu na 1. poschodí brány (Loydl 2012, 3).

V rokoch 2009-2010 prebiehala $\mathrm{v}$ priestore tretej brány úprava sut’ového zásypu, aby odviedol dažd’ovú vodu. Zároveň očistili schody z vel'kého nádvoria do suterénu tretej brány (Loydl 2012, 3). Ešte v roku 2010 členovia združenia Rondel opravili štyri delové striel'ne horného hradu a pláštový múr. Pracovali aj na zamurovaní otovorov na juhozápadnom nároží hlavnej veže. Tretia brána bola zakrytá skrytou pultovou strechou na úrovni tretieho podlažia s ciel’om definitívne zamedzit' erózii murív a klenby, ktorú spôsobovala dažd’ová voda.

Architektonický prieskum hradu realizovala už D. Menclová, ktorá upriamila pozornost' najmä na gotickú obytnú vežu (rukopisná pozostalost' autorky, Národní muzeum Praha). Pôdorys s datovaním stavebných objektov je publikovaný v súbornom spracovaní slovenských hradov (Plaček-Bóna 2007, 88-91). Autor hesla M. Bóna na základe nepublikovaného výskumu R. Vrlu uvádza ako najstaršiu stavbu hradného areálu hranolovú obytnú vežu na najvyššom bode hradného areálu. Na južnej strane k nej priliehalo približne obdížnikové nádvorie. Do konca 15. storočia vzniklo opevnenie predhradia vysunutého severným smerom a súčasne hrad zosilnilo niekol'ko nových bášt. Do 16. storočia sa datuje rozšírenie hradného opevnenia o renesančné druhé, tretie a štvrté predhradie (obr. 5). Súčast’ou týchto prestavieb mala byt' aj výstavba skúmanej tretej brány. V roku 2011 vypracoval v rámci prípravy obnovy architektonicko-historický výskum tretej brány M. Šimkovic. Výskum neskôr doplnil o vyhodnotenie situácií odkrytých sondážnym archeologickým výskumom. Archeologický výskum na hrade Čabrad' v rokoch 2013-2015 prebiehal v súčinnosti s prípravou obnovy druhej a tretej brány a konzervačnými prácami. Viedol ho Ján Beljak v spolupráci s Maximom Mordovinom (obr. 7). 


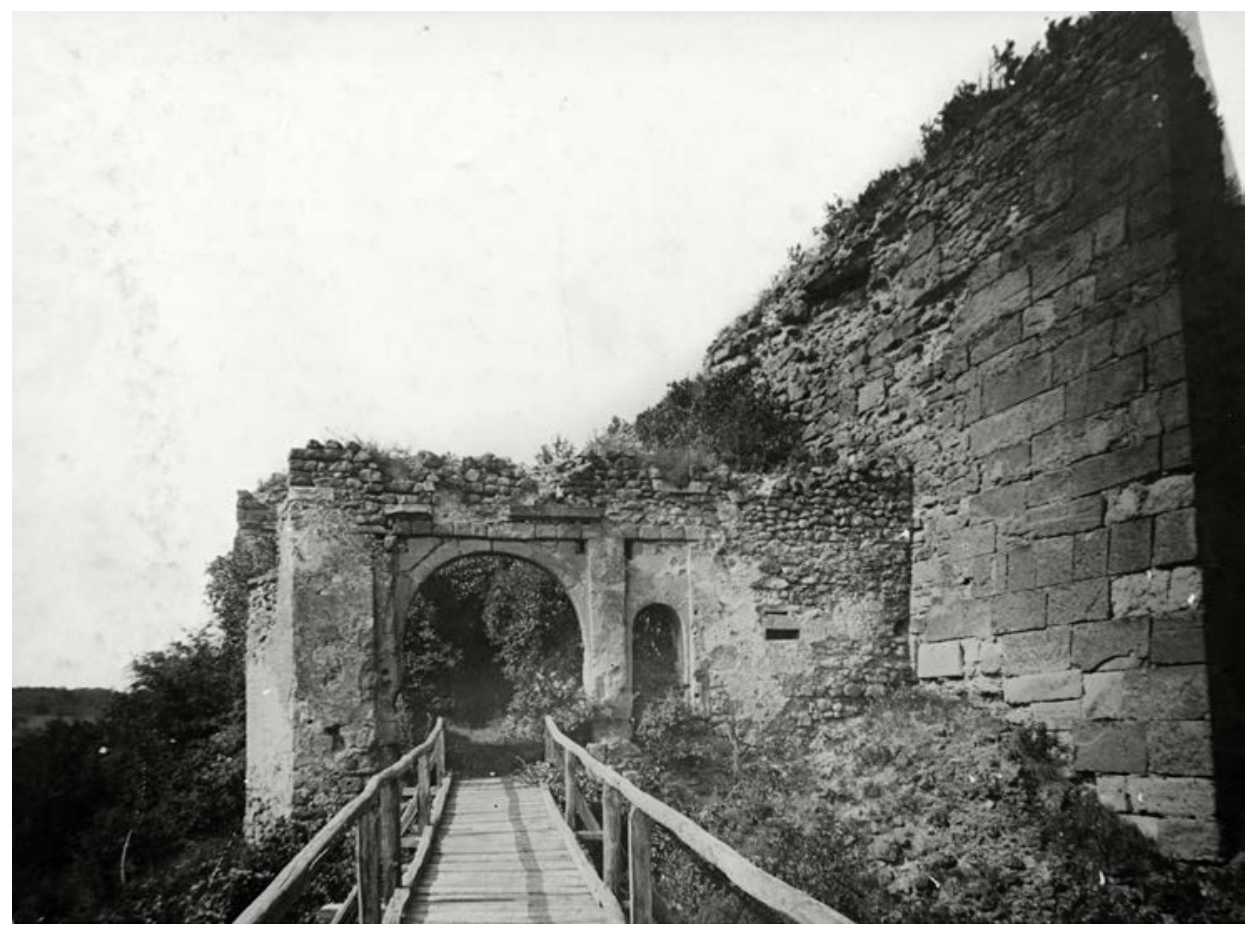

Obr. 5. Hrad Čabrad', okr. Krupina. Fotografia prvej brány v závere 19. storočia. Zdroj Forster Gyula Nemzeti Örökségvédelmi és Vagyongazdálkodási Központ, inv. č. N: 159339.

Abb. 5. Burg Čabrad', Bezirk Krupina. Fotografie des ersten Tores vom Ende des 19. Jahrhunderts. Quelle Forster Gyula Nemzeti Örökségvédelmi és Vagyongazdálkodási Központ, Inv.-Nr. N: 159339.

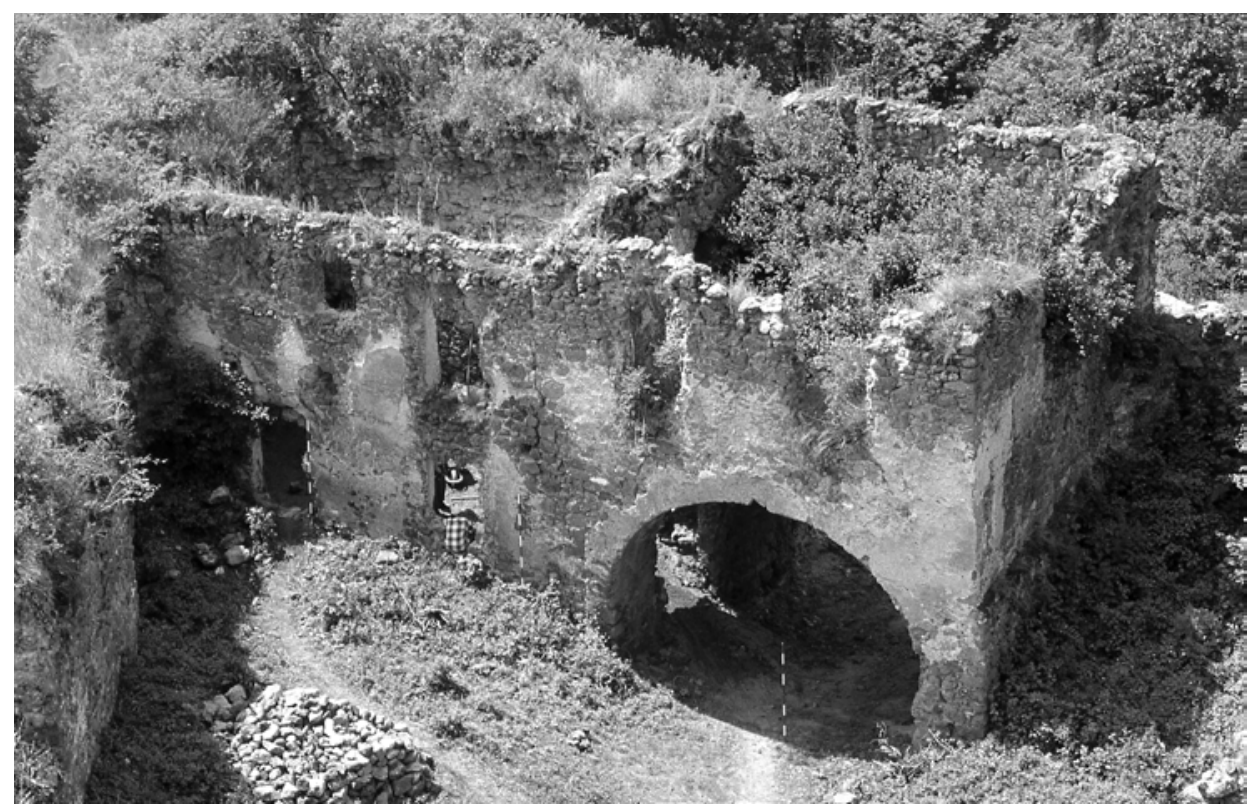

Obr. 6. Hrad Čabrad', okr. Krupina. Druhá brána počas archeologického výskumu v roku 1997. Foto V. Hanuliak.

Abb. 6. Burg Čabrad', Bezirk Krupina. Das zweite Tor während der archäologischen Grabung von 1997. Foto V. Hanuliak. 


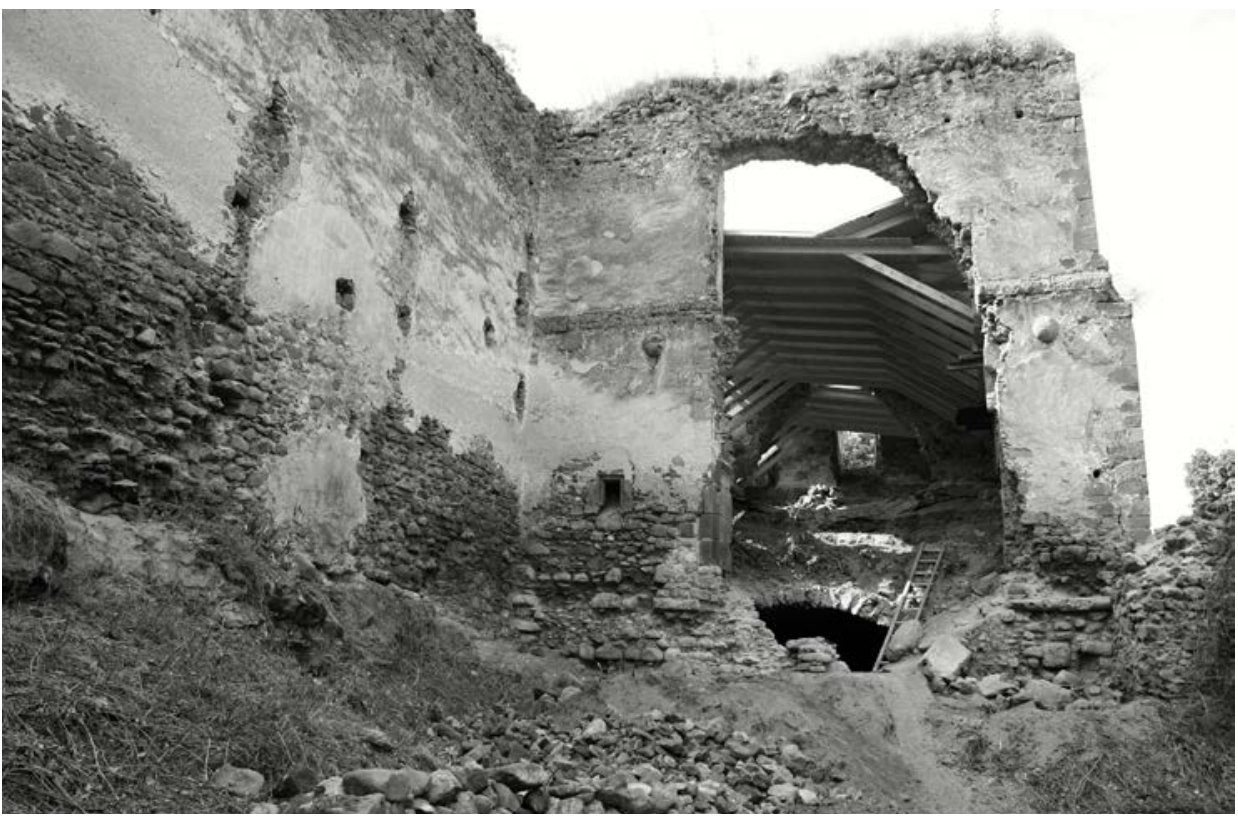

Obr. 7. Hrad Čabrad', okr. Krupina. Južné priečelie tretej brány počas archeologického výskumu v roku 2013. Foto J. Beljak. Abb. 7. Burg Čabrad', Bezirk Krupina. Südfassade des dritten Tores während der archäologischen Grabung von 2013. Foto J. Beljak.

\section{Vlastníci hradu v stredoveku a najstaršia brána}

Hrad Čabrad' (pôvodne Litava) mohol podla zistení doterajšieho historického výskumu vzniknút' v prvých desat'ročiach 14. storočia, po zániku blízkeho staršieho hradu Hrádok (rovnako nazývaný aj Litava). Za jeho stavebníkov možno azda označit' Petra a Leukuša, synov Vavrinca z Dobra Kuće (v Križevatskej stolici). V roku 1342 im kvôli násilným činom král' Karol Róbert hrad Litavu odňal. Listina vtedy spomína dva hrady: Litava - nový hrad a opustený hrad (Györffy 1987, 217; Plaček-Bóna 2007, 88, 190; CDH VIII, 594 č. CCCII). V nasledujúcich desat'ročiach bol hrad v král’ovských rukách. Pred rokom 1387 ho dcéra L’udovíta I., král'ovná Mária, zálohovala za 3000 zlatých Frankovi zo Sečian. Máriin manžel Žigmund Luxemburský hrad Litavu Frankovi odobral a v roku 1390 ju daroval svojmu dvoranovi Leustachovi z Jelšavy. Leustach zakrátko dostal od krála súhlas, aby Litavu vymenil za hrad Sivý Kameň. Po d'alších vlastníckych zmenách sa tak v roku 1394 stal novým majitel'om hradu, označeného ako Pustá Litava (Puztalythwa), Ladislav Kakaš z Kazy (v Boršodskej stolici; Bakács 1971, 47-48; ZsO I, č. 20, 1367, 1408, 1464, 3587). V roku 1415 král’ Žigmund udelil svojim dvorským rytierom Duulovi (Gyula) a Lorandovi, synom Ladislava Kakaša, novú donáciu na ich rodové majetky. Hrad aj vtedy vystupuje ako pustý (desertum; ZsO V, č. 504) a v nasledujúcich rokoch o ňom chýbajú správy.

V období rozbrojov, ktoré $\mathrm{v}$ širšom regióne prebiehali od 40. rokov 15. storočia, na opustenom hrade sídlila posádka českého pôvodu - bratríci. O ich prítomnosti svedčí obliehanie hradu král'ovským vojskom za účasti panovníka. V októbri a novembri 1461 vydal Matej Korvín v tábore pod pevnost’ou Litava (sub fortalicio Lythwa) viaceré písomnosti (Miňo 2010, 81-84; Horváth 2011, 69). K udalostiam sa vracajú dve listiny z roku 1469. Podl'a nich král' hrad Litavu vydobyl od „českých heretikov“, pričom krajinský sudca zároveň riešil spor, ktorý prepukol v čase, ked' král' uskutočnil výpravu proti pevnosti Čabrad' (castellum Chabrad; MNL DL 46 857, 98257). Nový názov spolu s prívlastkami fortalitium a castellum naznačuje okrem vlastníckych zmien aj stavebnú úpravu hradu. Hoci pramene nad’alej používali i názov Litava, postupne prevládlo pomenovanie Čabrad'. 
Vlastníkom hradu sa stal visegrádsky kastelán Damián Horvát. Počas dedičského konania po jeho smrti nachádzame prvé konkrétne doklady o stavebnom členení hradu. V roku 1475 uhorský palatín riešil spor o del'bu hradu medzi Eufrozínou, vdovou po Damiánovi, a jej švagrom Petrom Horvátom. Vyslaný zástupca vtedy doručil rozsudkovú listinu osobne k bráne hradu (ad portam predicti castri). Eufrozína s Petrom si následne hrad rozdelili na polovicu (MNL DL 45620 ). Del'bu zaznamenáva listina z roku 1476 . Z opisu je zrejmé, že stavbu v tom čase tvoril iba tzv. horný, či vnútorný hrad. Areál tvorili viaceré objekty, medzi nimi aj opakovane spomínaná brána. Nad bránou (presnejšie na návrší vedl’a nej) stála obytná veža. V bašte vedl’a brány býval kováč, ktorý mal slúžit’ obom stranám. V tej istej bašte (in eadem bastha) sa nachádzali aj stajne, rozdelené na dve časti. Čast' na strane od hradu mal užívat' Peter a druhú stranu od doliny mala užívat' Eufrozína (Balassa cs. 1t., 142, č. 411; porov. Ratkoš 1958, 95-96; Hanuliak 2004, 300). Horvátovci po sebe zanechali najmä dcéry, čo viedlo k d’alšiemu deleniu majetkov, ale i k nezhodám medzi spoluvlastníkmi. Azda aj preto už v roku 1503 predali hrad s príslušenstvami ostrihomskému arcibiskupovi Tomášovi Bakóczovi a jeho bratrancovi Valentínovi Erdődymu (SNA, HM HB, Autentický protokol A, fol. 90r-v). V roku 1517 král' L’udovít II. potvrdil znenie testamentu Tomáša Bakócza. Podl'a neho mali po jeho smrti zdedit' celý hrad Čabrad's panstvom Štefan a Farkas (Wolfgangus), synovia nebohého Valentína Bakócza z Erdődu (Szántófy 1869, $525,527)$. Stavebnú činnost' podl’a staršej literatúry dokumentoval nápis na bašte vpravo na nádvorí vnútorného hradu. Hlásal, že baštu dal v roku 1520 vybudovat’ arcibiskup Tomáš Bakócz († 1521; Thaly 1867, 26; Hanuliak 2004, 303). Nie je zrejmé, či išlo o úplne nový objekt, alebo či nemožno uvažovat' aj o prebudovaní vyššie uvedenej bašty vedl'a brány.

\section{Písomné doklady o renesančnej hornej bráne}

Pravdepodobne v pomoháčskom období vtedajší majitelia Erdődyovci (Pálffyovci) opevnili Čabrad' novým obvodovým múrom s baštami a bránou. Dobové pramene používali pre toto opevnenie označenie dolný hrad, na rozdiel od staršieho horného hradu. Vstup do areálu zabezpečovala dolná alebo vonkajšia brána (Maliniak 2016, v tlači). Počas stavebných úprav došlo k výraznej prestavbe (deštrukcii?) pôvodnej stredovekej brány horného hradu, pričom sa podobnému osudu nevyhla ani bašta vedl’a brány, v ktorej žil kováč a zároveň v nej boli stajne. O zmene využívania priestorov vypovedajú hradné inventáre. Hoci podl’a súpisu zariadenia z roku 1558 sa na Čabradi nachádzalo kováčske náčinie a nasekané železo, kováčsku vyhňu už nachádzame pri mlyne a majeri pod hradom. ${ }^{1}$ Priamo na hrade došlo $\mathrm{k}$ vybudovaniu novostavby stajní. Podl'a vyúčtovania stavebných prác z roku 1561 boli na hrade nanovo postavené drevené stajne pre 40 koní. Rovnaký dokument zároveň spomína, že vtedajší zálohový vlastník hradu Ján Kružič dal za pomoci banskoštiavnických majstrov vybudovat' aj akúsi baštu (propugnaculum) položenú smerom $\mathrm{k}$ doline, spolu s pevnou klenbou (cum testudine firmissima) pod uvedenou baštou, s objemom 636 siah kameňa v hodnote 3180 zlatých. ${ }^{2}$ Pri porovnaní s nasledujúcimi dokladmi nemôžeme vylúčit' nadväznost' tohto objektu na hornú bránu.

O vnútornom členení a zariadení brány horného hradu poznáme rôznorodé údaje. Za prvý hodnoverný doklad o existencii skúmanej renesančnej brány je možné považovat' inventár z februára roku 1558. Inventár uvádza vstup do tohto areálu, ked’ menuje hornú bránu, presnejšie zbrane umiestnené pod hornou bránou (sub porta superiori). Túto zmienku je možné dat' do súvisu s dodnes zachovaným suterénnym obranným podlažím bránovej budovy. Rovnaký inventár totiž spomína palnú zbraň (falkonet), umiestnenú nad obytnou bránou, pre ktorú používa prívlastok kapitánska (supra portam habitacionem, scilicet capitanei). Súčastou tohto objektu je väčšia zaklenutá pivnica. V roku 1558 máme správy o dvoch zaklenutých miestnostiach. V prvej, označenej ako klenba pod schodmi (In testudine sub gradu), boli uložené zásoby pušného prachu, streliva a zbraní. Pod d'alšou klenbou (In una testudine) bolo uskladnené víno.

1 MNL, MKA, E 211 Lymbus, Ser. III, 22. tétel, 36. szám, 135. csomó, fol. 213r; MNL, MKA, E 156 UetC, fasc. 4, num. 48, pag. 135.

2 MNL, MKA, Miscelanea, E 210 Militaria, 47. csomó, 12. tétel, fol. 587r; MNL, MKA, E 156 UetC, fasc. 100, num. 18, pag. 2. 
Tento objekt však nasledoval až za dvomi pivnicami umiestnenými pod hlavnou obytnou vežou, v ktorých bolo tiež víno. Údaje o zabezpečení najpravdepodobnejšie dverí v hornej bráne dopín̆a inventár vyhotovený v októbri 1558. Spomína tri zámky alebo závory v hornej bráne (Serae in porta superiori 3$){ }^{3}$ Popri zbraniach a vojenskom náčiní poznáme i zariadenie interiéru. Inventár z roku 1602 spomína najprv výzbroj (1 falkonet a 15 hákovníc) v hornej bráne a na inom mieste znovu výzbroj (6 hákovníc) a zariadenie v nešpecifikovanej bráne. Môžeme však usudzovat', že znovu išlo o obytnú hornú bránu. Nachádzalo sa v nej 5 vel'kých zámok, 11 štvorcových a pozdížnych stolov, 9 stoličiek s operadlami a 9 postelí. ${ }^{4}$ Mobiliár azda slúžil najmä vojakom strážiacim bránu.

K hornej bráne, resp. jej obrane, možno zaradit' aj údaj z roku 1625. Vo veži nad bránou sa vtedy nachádzali dva falkonety. Identifikácii by zodpovedal aj údaj z roku 1625, ked'sa dozvedáme o zásobách v menšej zbrojnici pri bráne (In domo armamentario minori penes portam). Rovnaký prameň uvádza aj zásoby vo väčšej zbrojnici vo veži (In turri sive armamentario maiori). ${ }^{5}$ Pokial' zohl'adníme údaj o uskladnenej výzbroji pod klenbou, nemožno vylúčit', že objektom s nezmenenou funkciou a polohou je menšia zbrojnica. Ikonografické pramene: plán hradu z rokov 1572-1573 a veduta okolo roku 1580 (obr. 8, 9; vyhotovili ich talianski stavitelia bratia Natale a Nicolo Angieliniovci), ako aj dva identické plány zo 17. storočia (bez autorstva) zobrazujú hornú bránu bez výrazných zmien. Objekt s charakterom prejazdnej veže mal podla zobrazení nepravidelný lichobežníkový pôdorys. Pozostával minimálne z troch podlaží, pričom na úrovni prízemia do vnútorného hradného nádvoria vyúst’ovala brána orientovaná v osi objektu. Zobrazenie pod strechou pripomína ochodzu (Kisari Balla 2000, 187, 564, č. 305; Hanuliak 2004, 301; Plaček-Bóna 2007, 89; Kisari Balla 1998, 57, 107, č. 27; 1996, 51, 89, č. 27).

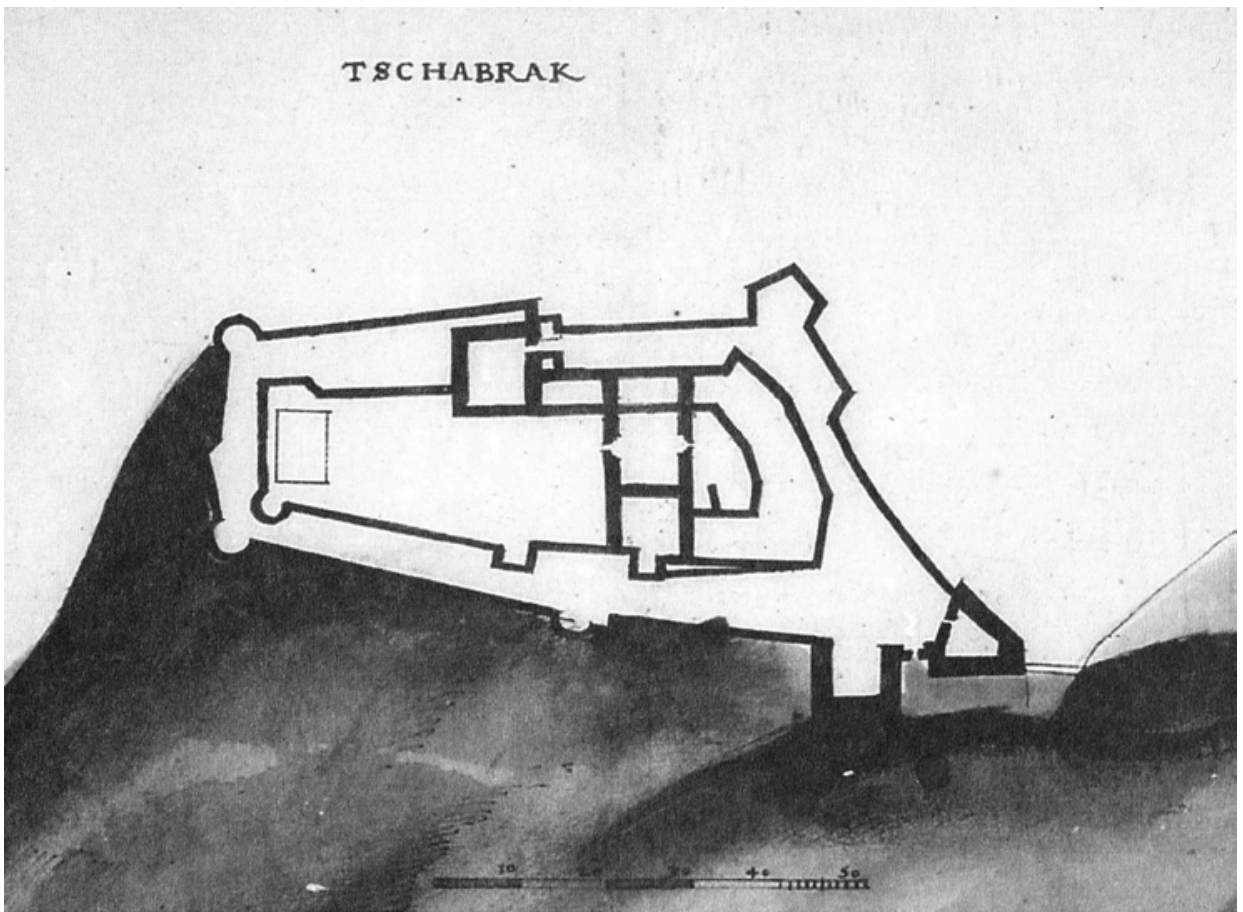

Obr. 8. Plán hradu Čabrad’ z roku 1572-1573 od Nicola Angieliniho. Podl’a Kisari Balla 1998, 107, č. 27.

Abb. 8. Plan der Burg Čabrad' aus den Jahren 1572-1573 von Nicolo Angielini. Nach Kisari Balla 1998, 107, Nr. 27.

3 MNL, MKA, E 211 Lymbus, Ser. III, 22. tétel, 36. szám, 135. csomó, fol. 212r-v, 214v; MNL, MKA, E 156 UetC, fasc. 4, num. 48, pag. 135.

4 MNL, MKA, E 156 UetC, fasc. 76, num. 11, pag. 22, 24-25.

5 MNL, MKA, E 156 UetC, fasc. 78, num. 12, pag. 20-21. 


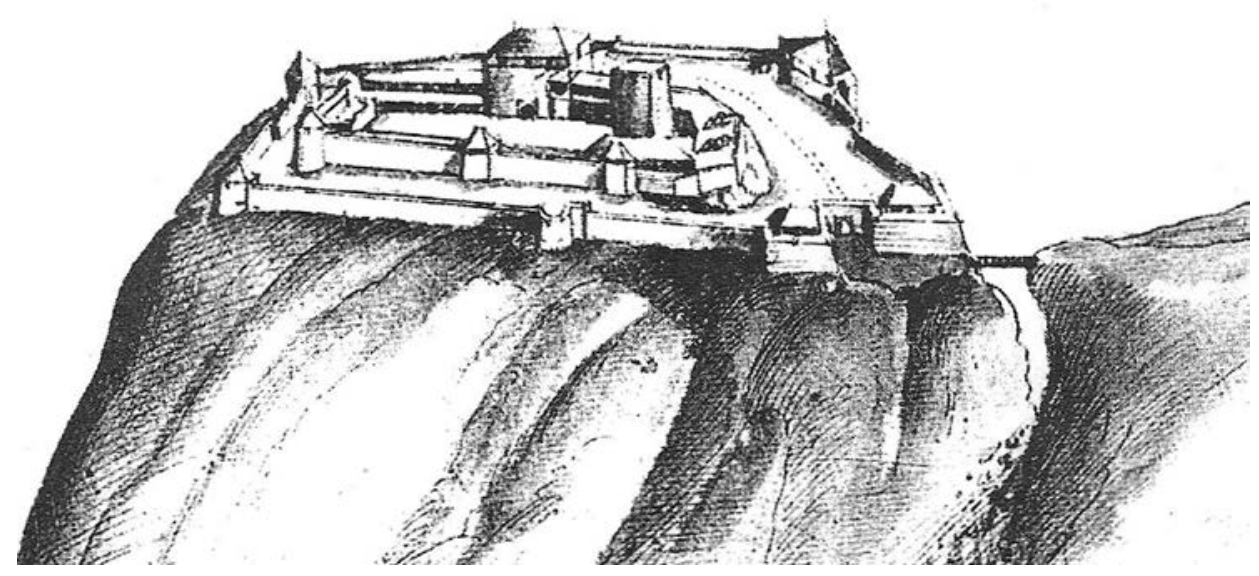

Obr. 9. Axonometrická veduta hradu Čabrad' okolo roku 1580. Pohl’ad od juhozápadu. Podl’a Plaček-Bóna $2007,89$. Abb. 9. Axonometrische Ansicht von Burg Čabrad' um das Jahr 1580. Blick aus Südwest. Nach Plaček-Bóna $2007,89$.

\section{Architektúra brány}

Budovu tzv. tretej (pôvodnej hornej) brány hradu Čabrad' tvorí mohutná stavba obdížnikového pôdorysu s vonkajšími rozmermi takmer $20 \times 13 \mathrm{~m}$, pristavaná z vonkajšej strany $\mathrm{k}$ hradbe prvého predhradia. Brána založená do bočného svahu hradného vrchu má tri podlažia (obr. 10, 17). Spodné podlažie malo z pohladu nádvoria predhradia charakter suterénu, smerom do exteriéru jeho múry v dôsledku klesania terénu vystupovali nad terén (obr. 13, 17). Suterén prístupný z nádvoria cez zaklenuté schodisko malo v prvom rade obranný charakter. Svedčia o tom komorové striel'ne pre palné zbrane, orientované na východnú a severnú stranu. Tieto striel'ne situované v úrovni podlahy suterénu dopín̆ali ešte dve striel'ne v čelných stenách položené vysoko nad podlahou suterénu. Ich vyvýšenú polohu vyžiadala stúpajúca úroveň vonkajšieho terénu. Tieto striel'ne majú, na rozdiel od komorových, jednoduchšiu podobu s dovnútra aj von rozšírenými osteniami. Zatial' čo strielňa na severnej strane je dnes z vonkajšej strany takmer úplne zasypaná, vonkajšiu čast' striel'ne na južnej strane odkryla sonda č. 1/2013. Striel'ňa osadená do soklovej časti fasády brány pokrývala priestor priekopy pod úrovňou padacích mostov. Archeologický výskum v priestore pred bránou odkryl murovaný pilier, odl’ahčený dvojicou oblúkov armovaných opracovanými kvádrami. Oblúky zrejme zabezpečovali možnost' obrany priekopy zo strielní obranného suterénu.

V prízemí budovy bol situovaný prejazd vstupnej brány (obr. 14, 16, 17). Vstup do hradu viedol cez dva portály v čelnej južnej stene - široký hlavný a menší bočný pre peších (obr. 12). Hlavný portál mal podl'a zachovaných odtlačkov v murive kamenné tesané ostenia, na ktoré nadväzovali rovné špalety z opracovaných kvádrov. Z ostenia hlavného portálu pochádzajú segmenty zistené $\mathrm{v}$ sonde $2 / 2013 \mathrm{~s}$ vpadlinou pre most, ktorá bola po obvode lemovaná plastickou bosážou. Ďalší fragment naznačuje, že portál mohol byt' na hornej strane ukončený rímsou.

Podl'a fragmentálne zachovaných detailov bol portál pôvodne uzatvorený padacím mostom vahadlovej konštrukcie. Manipuláciu s mostovkou zabezpečoval vahadlový trám s protizávažím, otáčajúci sa okolo osi zakotvenej v hornej časti portálu, ktorá sa žial’ nezachovala. Existenciu tejto konštrukcie dnes dokladá len čast' štrbinovej vpadliny vo fasáde brány nad portálom (obr. 7), do ktorej zapadala horná čast' vahadla. S tým korešponduje aj skutočnost', že okraj vpadliny lícuje s kolmou špaletou brány tak, že sa predpokladaný trám mohol otáčat' okolo svojej osi a sklápat' sa pozdíž špalety brány (obr. 14, 16). 


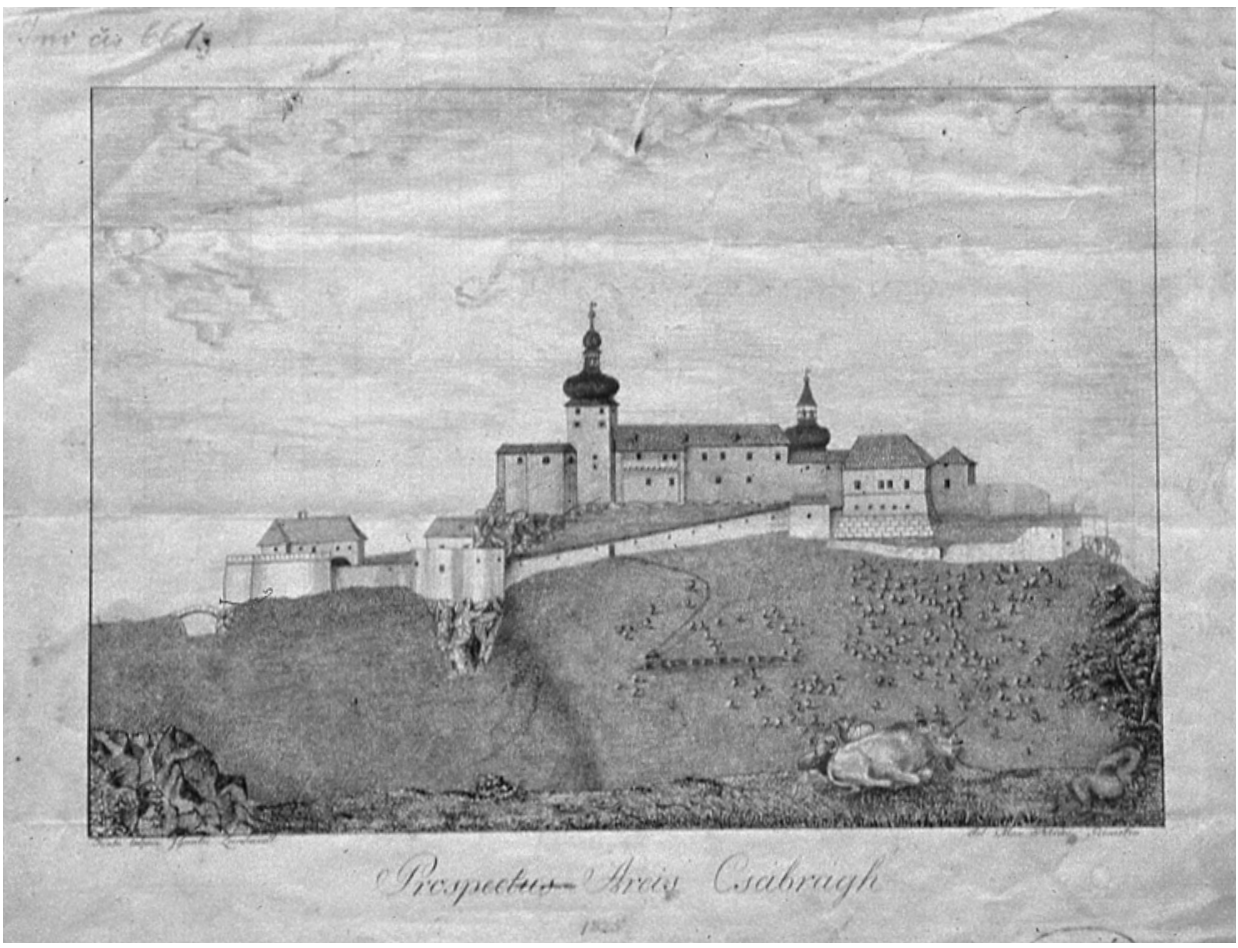

Obr. 10. Pohl'ad na hrad z východnej strany na kresbe zo začiatku 19. storočia. Podl’a Borovszky 1906.

Abb. 10. Blick auf die Burg von der Ostseite auf einer Zeichnung vom Beginn des 19. Jahrhunderts. Nach Borovszky 1906.

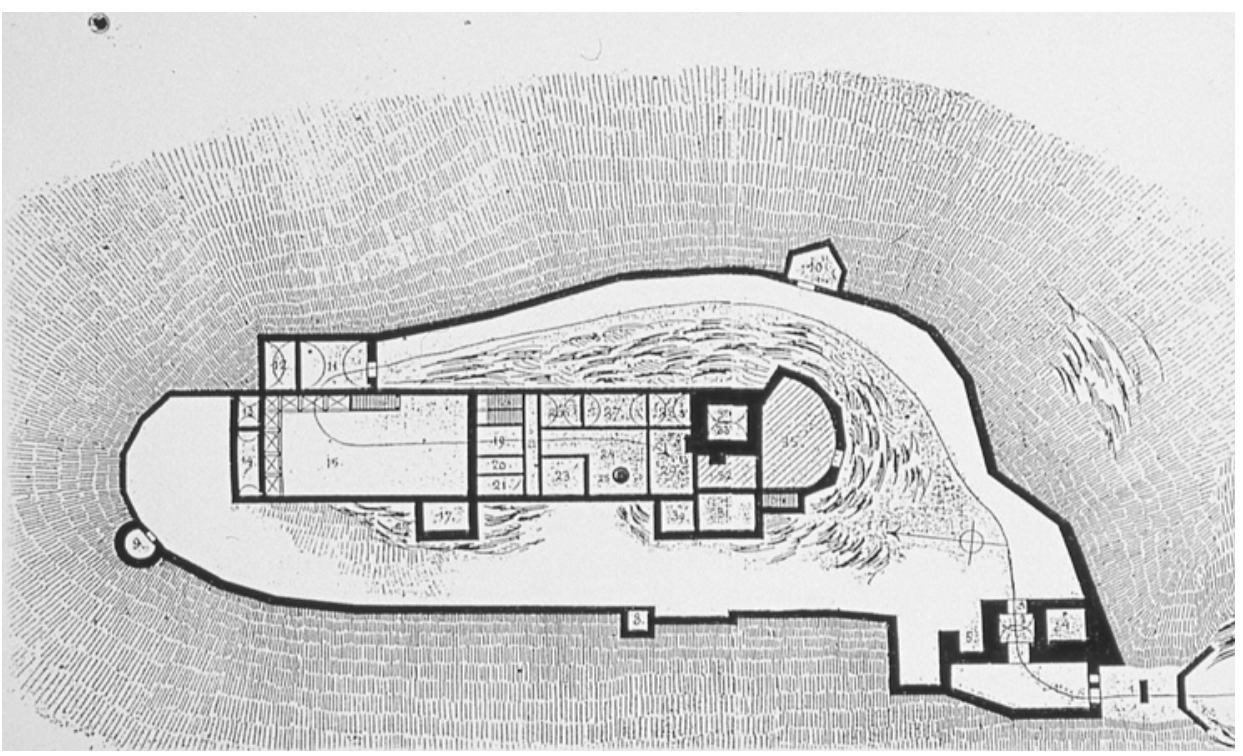

Obr. 11. Pôdorys hradu podl’a J. Kőnyőkyho z roku 1889. Podl’a Váliné Pogány 2000.

Abb. 11. Grundriss der Burg nach J. Könyőky aus dem Jahr 1889. Nach Váliné Pogány 2000. 
Na ostenie z vnútornej strany nadväzovali rovné špalety otvoru vybudované z opracovaných kvádrov. Rozmery portálu dnes vzhl’adom na úplnú deštrukciu západného ostenia nie je možné jednoznačne určit', pravdepodobne však svetlá šírka otvoru dosahovala okolo $280 \mathrm{~cm}$, výška podl’a zachovaného nábehu záklenku dosahovala okolo $360 \mathrm{~cm}$. Vedla hlavného portálu bol menší bočný vstup pre peších. Zachované torzo naznačuje, že podobne ako hlavný portál bol uzatvorený padacím mostom. Tu však absentujú stopy po vahadlovej konštrukcii mosta. Portál s výškou okolo $200 \mathrm{~cm}$ mal na vonkajšej strane vpadlinu s celkovou výškou okolo $290 \mathrm{~cm}$. Otvor ukončený polkruhovým záklenkom mal na vnútornej strane drážku pre dosadnutie vnútorných vrát brány (obr. 14, 16).

Vonkajšie portály brány viedli do rozsiahleho priestoru prízemia zastropeného trámovým stropom (obr. 14, 17). V rámci neho sa prístupová cesta zalamovala a ústila do nádvoria portálom s kamenným ostením, ktorý bol na vnútornej strane uzatvorený vrátami. Za vnútorným portálom bol krátky zaklenutý prejazd situovaný v spodnej časti rizalitu vystupujúceho z hmoty brány do nádvoria. Podobne ako suterén, aj prízemie brány bolo do exteriéru orientované deviatimi strielňami pre l’ahšie palné zbrane, rozloženými po celom vonkajšom obvode stavby. Pôvodný komín v rohu prízemia vedl’a bočného portálu dokladá, že tu bolo ohnisko alebo pec.

Prvé poschodie brány bolo na rozdiel od spodných podlaží trojpriestorové a malo obytný charakter (obr. 15, 17). Deliace priečky boli osadené na široké nosné oblúky, ktoré v úrovni prízemia ponechávali jednotný, nečlenený priestor. Obytné miestnosti horného podlažia boli samostane prístupné z nádvoria portálmi, ku ktorým zrejme viedla drevená pavlač. Jej existenciu naznačuje odtlačok zvislého dreveného trámu (vzpery) pod vstupom do západnej miestnosti. Obytný charakter horného podlažia dokladajú vel'ké okná v severnej a južnej miestnosti a prevét na severnej strane. Stredný priestor horného podlažia brány mal reprezentatívny charakter, ktorý bol zdôraznený vel'kým arkierom na východnej strane. Na protilahlej západnej strane smerom do nádvoria bol takmer rovnako široký oblúk, vedúci do horného podlažia rizalitu vysunutého do nádvoria. O podobe miestnosti v hornej časti rizalitu dnes nemáme žiadne poznatky.

Bránová budova sa svojimi rozmermi a architektúrou vymyká z kontextu bežných hradných brán. Ide o obytno-obrannú stavbu s prejazdom vstupnej brány. Popri obrannom charaktere stavby sa výrazne uplatnili aj výtvarné detaily. Masívny rozšírený sokel, do ktorého ústia striel'ne spodného podlažia, je na hornej strane ukončený kamennou rímsou. Ďalšia rímsa zdôrazňuje líniu ustúpeného najvyššieho podlažia stavby, ktoré malo na východnej strane vel'ký arkier osadený na profilovaných konzolách. Jeho pandantom smerom do nádvoria bolo horné podlažie rizalitu, u ktorého môžeme predpokladat' náročnejšie riešenie s vel'kými oknami. $Z$ tvaroslovných prvkov vnútorných priestorov sa zachovala len čast' vstupného portálu vedúceho do záchodového rizalitu. Poznatky o pôvodnej podobe brány dopíňa axonometrická kresba hradu hradu z obdobia okolo roku 1580 (obr. 9). Pozoruhodným detailom je, že nezachytáva rizalit vystupujúci zo západnej fasády smerom do nádvoria. Podl’a kresby sa zdá, že nad súčasným 2. nadzemným podlažím mohlo byt' ešte jedno, azda hrazdené podlažie.

\section{Mladšie stavebné úpravy brány}

Pôvodný vahladový most zrejme slúžil svojmu účelu pomerne krátko. Azda už v druhej polovici 16. storočia či na začiatku 17. storočia bol zrušený a vpadliny pre jeho nosné trámy boli zamurované. Nahradil ho bežný typ padacieho mosta - most tzv. kolískovej konštrukcie. Na jeho vybudovanie bolo potrebné vytvorit’ pod hlavným portálom šachtu na vnútorné pole mosta. Za týmto účelom bola vybúraná čast' muriva sokla pod portálom a v rámci steny bola vytvorená malá šachta s rozmermi $2,3 \times 1,3 \mathrm{~m}$. Jej vybudovanie si vyžiadalo oplentovanie vnútornej strany južnej steny smerom do suterénu (obr. 13, 14, 18).

V rámci neskorších úprav brány bola pôvodná pec situovaná vedl'a bočného vstupného portálu prestavaná na kúrenisko s kónickým dymníkom. Prestavba pece si vyžiadala vytvorenie nového okna na mieste strielne v južnej fasáde a zamurovanie otvoru v západnej stene do nádvoria. 


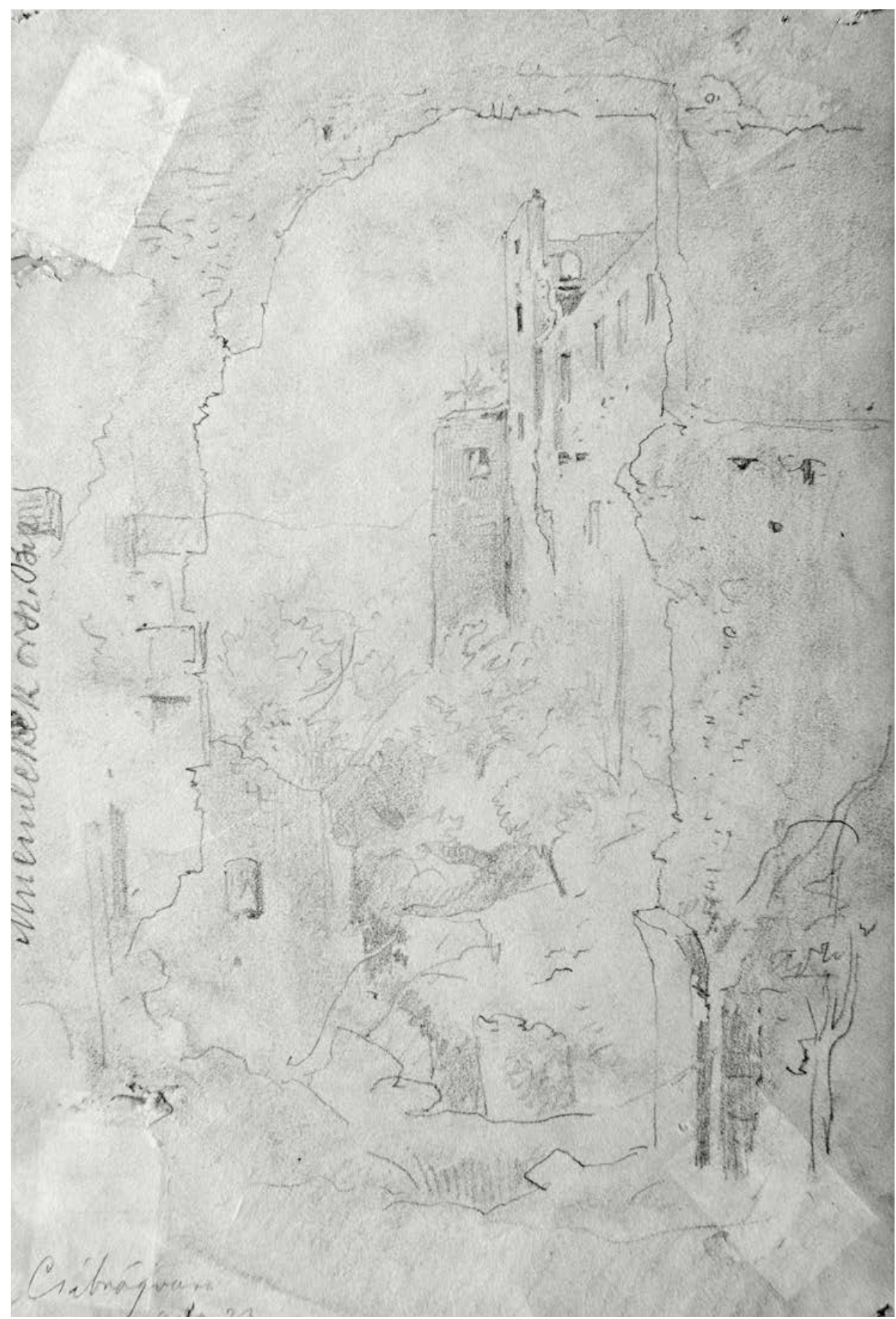

Obr. 12. Hrad Čabrad', okr. Krupina. Pohl’ad na nádvorie cez južné priečelie tretej brány v závere 19. storočia. Zdroj Forster Gyula Nemzeti Örökségvédelmi és Vagyongazdálkodási Központ, inv. č. N: 159339.

Abb. 12. Burg Čabrad', Bezirk Krupina. Blick in den Burghof durch die Südfassade des dritten Tores gegen Ende des 19. Jahrhunderts. Quelle Forster Gyula Nemzeti Örökségvédelmi és Vagyongazdálkodási Központ, Inv.-Nr. N: 159339. 


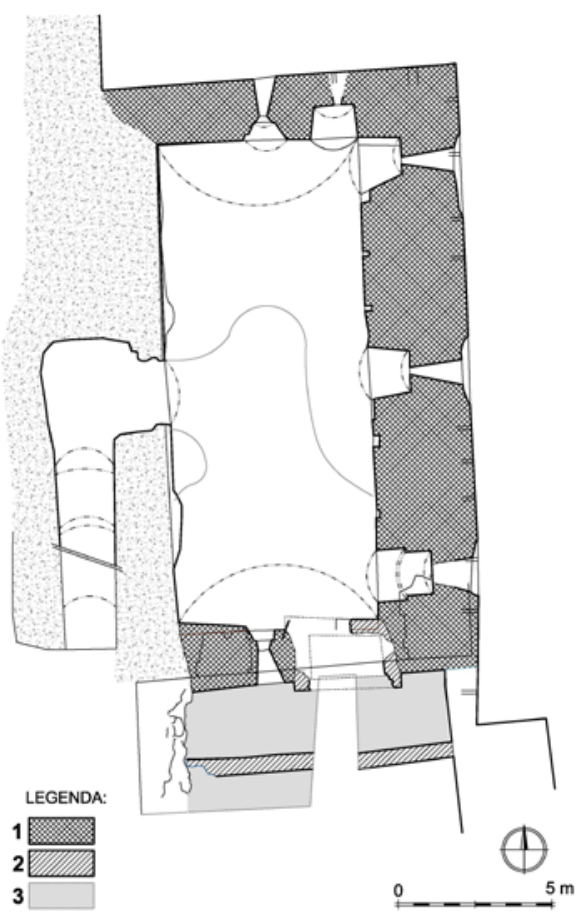

Obr. 13. Hrad Čabrad', okr. Krupina. Pôdorys suterénu tretej brány. 1 - murivo z polovice 16 . storočia, 2 - murivo z 2. polovice 16. - zač. 17. storočia, 3 - plochy preskúmané archeologickým výskumom. Vyhotovil M. Šimkovic. Abb. 13. Burg Čabrad', Bezirk Krupina. Grundriss des Souterrains des dritten Tores. 1 - Mauerwerk von Mitte des 16. Jahrhunderts, 2 - Mauerwerk aus der zweiten Hälfte des 16. - Anfang des 17. Jahrhunderts, 3 - durch archäologische Grabung untersuchte Flächen. Erstellt von M. Šimkovic.

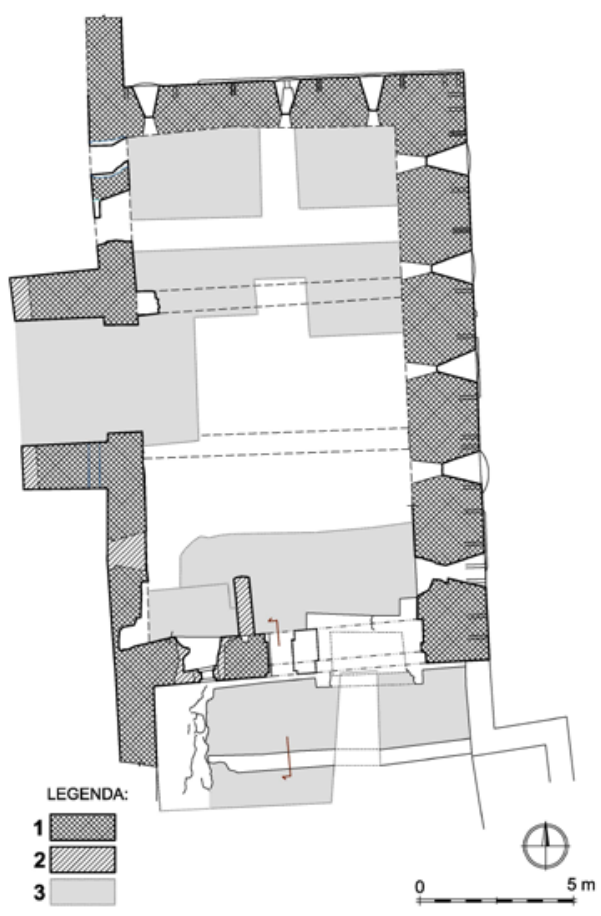

Obr. 14. Hrad Čabrad', okr. Krupina. Pôdorys prízemia tretej brány. 1 - murivo z polovice 16. storočia, 2 - murivo z 2. polovice 16. - zač. 17. storočia, 3 - plochy preskúmané archeologickým výskumom. Vyhotovil M. Šimkovic.

Abb. 14. Burg Čabrad', Bezirk Krupina. Grundriss des Erdgeschosses des dritten Tores. 1 - Mauerwerk von Mitte des 16. Jahrhunderts, 2 - Mauerwerk aus der zweiten Hälfte des 16. - Anfang des 17. Jahrhunderts, 3 - durch archäologische Grabung untersuchte Flächen. Erstellt von M. Šimkovic.

Výrazné stavebné úpravy brány je možné rámcovo datovat' do priebehu 17. storočia (obr. 13-15). Priestor suterénu ostal v tomto období prakticky bez zmien. Priestor oboch nadzemných podlaží bol zaklenutý valenými klenbami. Vel'ké stavebné úpravy sa dotkli predovšetkým obytných priestorov horného podlažia. Pôvodná priečka medzi strednou a južnou miestnostou bola úplne zbúraná a spomenuté dve miestnosti sa zjednotili do jedného vel'kého priestoru. Zbúranie priečky umožnilo vedl'a vstupu do arkiera vybúrat' v hmote muriva rohovú niku, do ktorej zrejme bola osadená pec. Tento predpoklad vychádza z interpretácie kresby hradu z 18. storočia, kde je nad východnou stenou zakreslené komínové teleso. V rámci neskororenesančných úprav boli priestory horného podlažia zaklenuté klenbami.

Rozsiahle stavebné úpravy budovy brány súvisia aj s vybudovaním arkádovej chodby pozdíž západnej fasády. Chodba spájala budovu na severnej strane nádvoria s obytnými traktmi v jeho južnej časti. Potrebe vybudovania chodby muselo ustúpit' horné podlažie rizalitu. Súčast’ou rozsiahlej adaptácie stavby bolo aj kompletné omietnutie jej interiéru a fasád novou vrstvou omietok. V obytných priestoroch druhého podlažia mali omietky pôvodne mal'ované sokle bordovej farby, ktoré boli neskôr plošne zmenené na čierne.

Stavebný vývoj skúmanej brány uzatvárajú čiastkové stavebné úpravy, ktoré môžeme rámcovo datovat' do záverečného obdobia existencie hradu. Jednou z týchto úprav bola zrejme prestavba horného podlažia chodbového traktu na obytné priestory. Do rámca týchto úprav je možné zaradit’ aj vybúranie dvoch komínových telies v dvorovej stene brány a čiastkové úpravy okien a vstupov v západnej fasáde. 


\section{Keramické nálezy z Čabradského hradu}

Počas troch sezón archeologického výskumu na hrade Čabrad' (obr. 13) bolo v priestore druhej, a predovšetkým tretej brány i severného paláca vel'kého nádvoria objavených približne 70 tisíc kusov hnutel'ných archeologických nálezov. Najväčšiu skupinu tvoria zvieracie kosti. Druhú najpočetnejšiu skupinu tvorí viac ako 34 tisíc fragmentov keramických nálezov. To nám dovolilo vytvorit' kvalitnú databázu pre predbežné vyhodnotenie niektorých súborov keramiky.

Najdôležitejšia a najpočetnejšia skupina nálezov pochádza z priekopy pred južnou fasádou tretej brány, ktorá bola stratigraficky dobre odlíšitel'ná. Priekopa bola skúmaná do híbky 3,5 až $4 \mathrm{~m}$. Obsahovala vrstvy datované predovšetkým do 18. storočia (aj 20 nálezov mincí, napr. z rokov 1670, 1696, 1699, 1700, $1707,1708,1762,1763,1781$ a 1782). Dno priekopy sa z dôvodu statiky a bezpečnosti nepodarilo doskúmat' až po geologické podložie a nevieme určit' jej celkovú híbku. Je pravdepodobné, že bola funkčná do prvej tretiny 18. storočia, zrejme do konca Rákociho povstania (1711). Následne ju začali postupne zasýpat' odpadom z hradu.

Podla historických prameňov hrad stratil svoju pôvodnú rezidenčnú funkciu po polovici 18. storočia $\mathrm{v}$ súvislosti $\mathrm{s}$ výstavbou svätoantonského kaštiel'a. Vyhodnotenie keramických nálezov z priekopy nám nevie zodpovedat' na otázku, ako sa zmenilo kvalitatívne zastúpenie keramiky po presunutí rezidenčnej funkcie do Svätého Antona. Nie sú viditel'né zmeny v pomeroch a kvalite nálezov prvej a druhej polovice 18. storočia. Celkove sa keramický materiál skladá z troch väčších súborov: kuchynská, stolová keramika a kachlice.

Prevažná väčšina novovekých nálezov pochádza zo sond 1-2/2013 a 1-2/2014, ktoré sa nachádzali v priestore priekopy pred tretou bránou. Stratigrafické jednotky priekopy boli dobre čitatel'né. Počas výskumu sme identifikovali tri výrazné stratigrafické jednotky. Prvá, vrchná vrstva sa skladala zo sutinových závalov obsahujúcich architektonické články z južného renesančného portálu a fragmenty opracovaného červeného mramoru. Tieto fragmenty pravdepodobne pochádzajú z pamätnej tabule, ktorá sa spomína $\mathrm{v}$ písomných prameňoch. Táto vrstva neobsahovala žiadne keramické a drobné nálezy. Bezprostredne pod ňou sa nachádzalo druhé súvrstvie. To sa skladalo z tmavých organických vrstvičiek, vel'mi bohatých na nálezy, popol a uhlíky. Tretie súvrstvie bolo takmer rovnaké ako druhé. Tvorili ho rovnaké popolové a organické vrstvy s vel'kým množstvom nálezov.

Obe spodné vrstvy sú datované do 18. storočia, pričom podla mincí a keramických nálezov je druhá vrstva o niečo mladšia ako tretia. Chronologický rozdiel je však minimálny. Nepresahuje 40-60 rokov medzi dolnou čast'ou tretej vrstvy a vrstvičkami skúmanými bezprostredne pod prvou sutovou vrstvou. Výplň priekopy vytvorili kuchynské a stavebné odpady, ktoré boli z interiéru tretej brány i d’alších častí hradu odstraňované počas modernizácie hradu. Povrdzuje to vel'ký počet kachlíc, ale aj vel'ký súbor okenného skla, kusy omietky a vel’a klincov. 


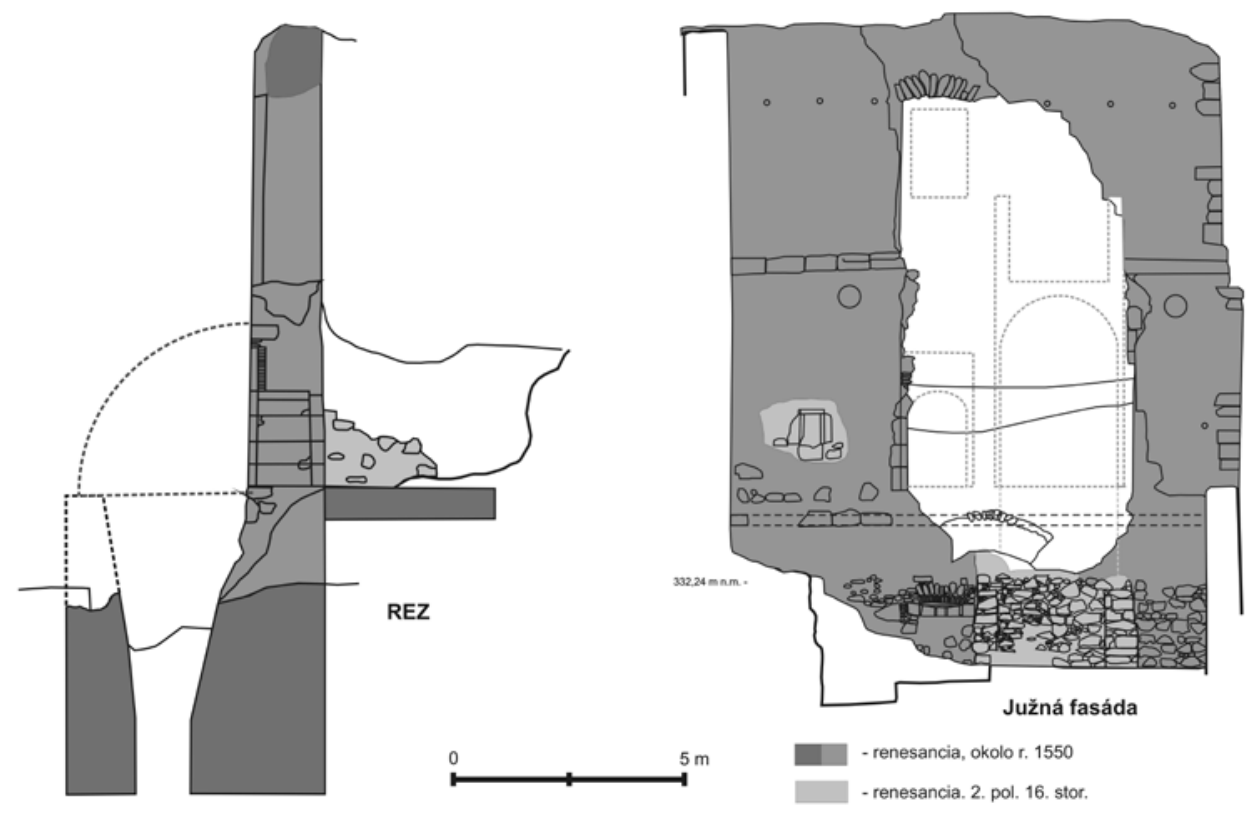

Obr. 16. Hrad Čabrad', okr. Krupina. Pohl'ad a rez južnou fasádou s vyznačením plochy skúmanej v rokoch 2013-2015. Vyhotovili M. Mordovin, M. Šimkovic a A. Loydl.

Abb. 16. Burg Čabrad', Bezirk Krupina. Blick auf die Südfassade und ihre Darstellung im Schnitt mit Kennzeichnung der in den Jahren 2013-2015 untersuchten Flächen. Erstellt von M. Mordovin, M. Šimkovic und A. Loydl.
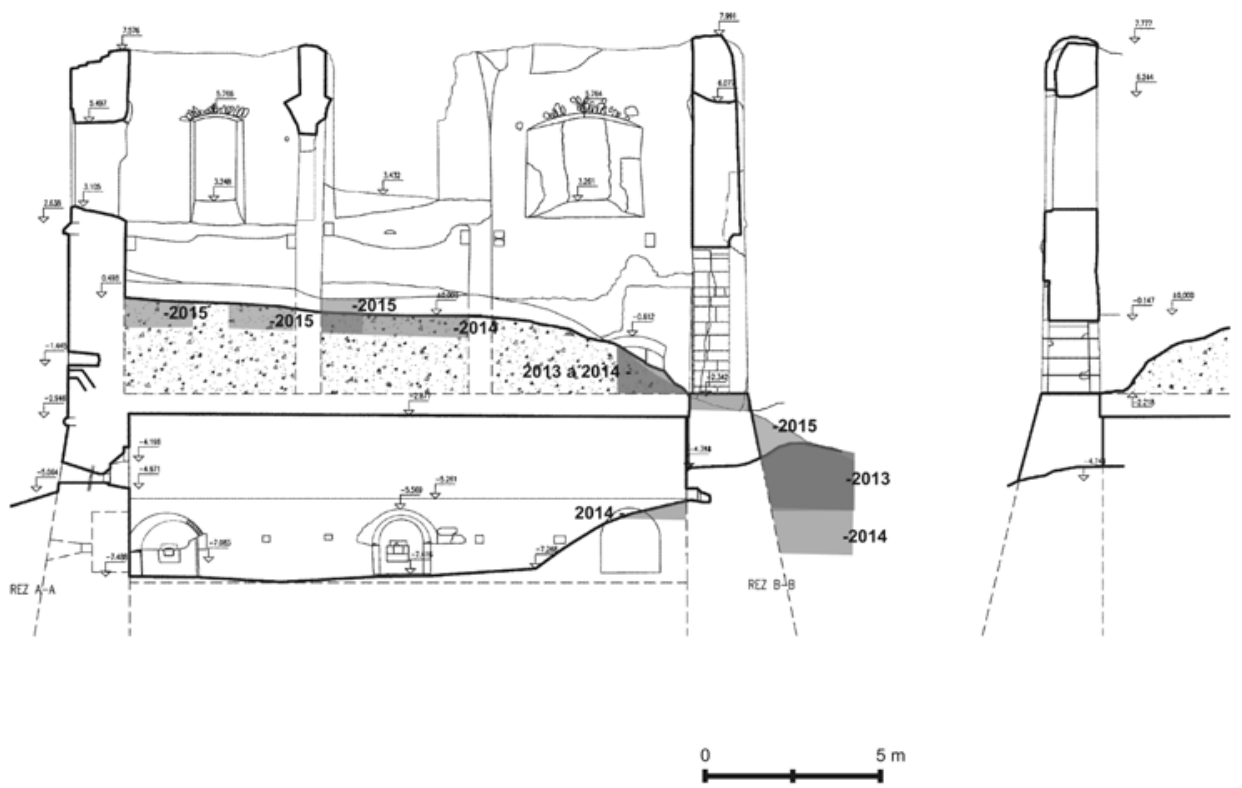

Obr. 17. Hrad Čabrad', okr. Krupina. Severojužný rez tret’ou bránou (pohl’ad zo západu) s vyznačením plochy skúmanej v rokoch 2013-2015. Vyhotovili M. Šimkovic a A. Loydl.

Abb. 17. Burg Čabrad', Bezirk Krupina. Nordsüdschnitt des dritten Tores (Blick von Westen) mit Kennzeichnung der in den Jahren 2013-2015 untersuchten Flächen. Erstellt von M. Šimkovic und A. Loydl. 


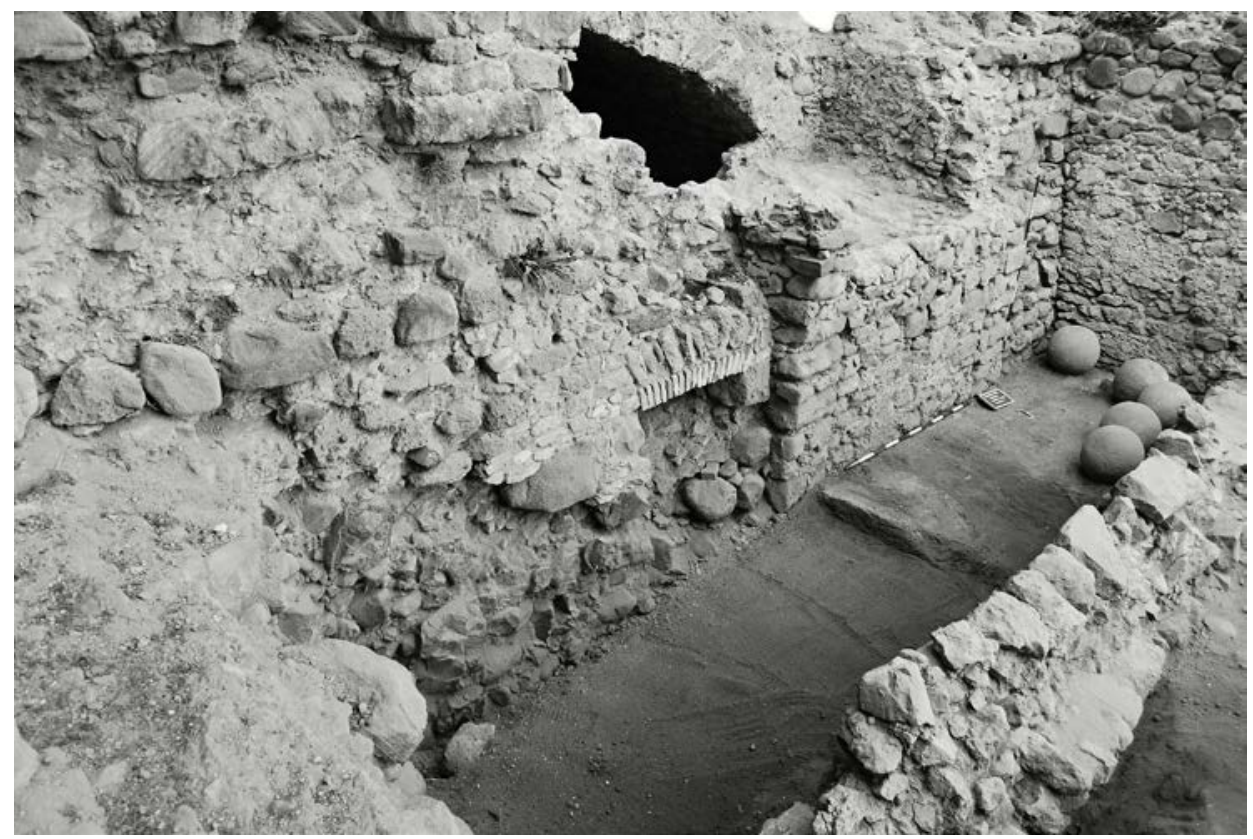

Obr. 18. Hrad Čabrad', okr. Krupina. Priekopa pred tret’ou bránou počas archeologického výskumu. Abb. 18. Burg Čabrad', Bezirk Krupina. Graben vor dem dritten Tor während der Ausgrabung.

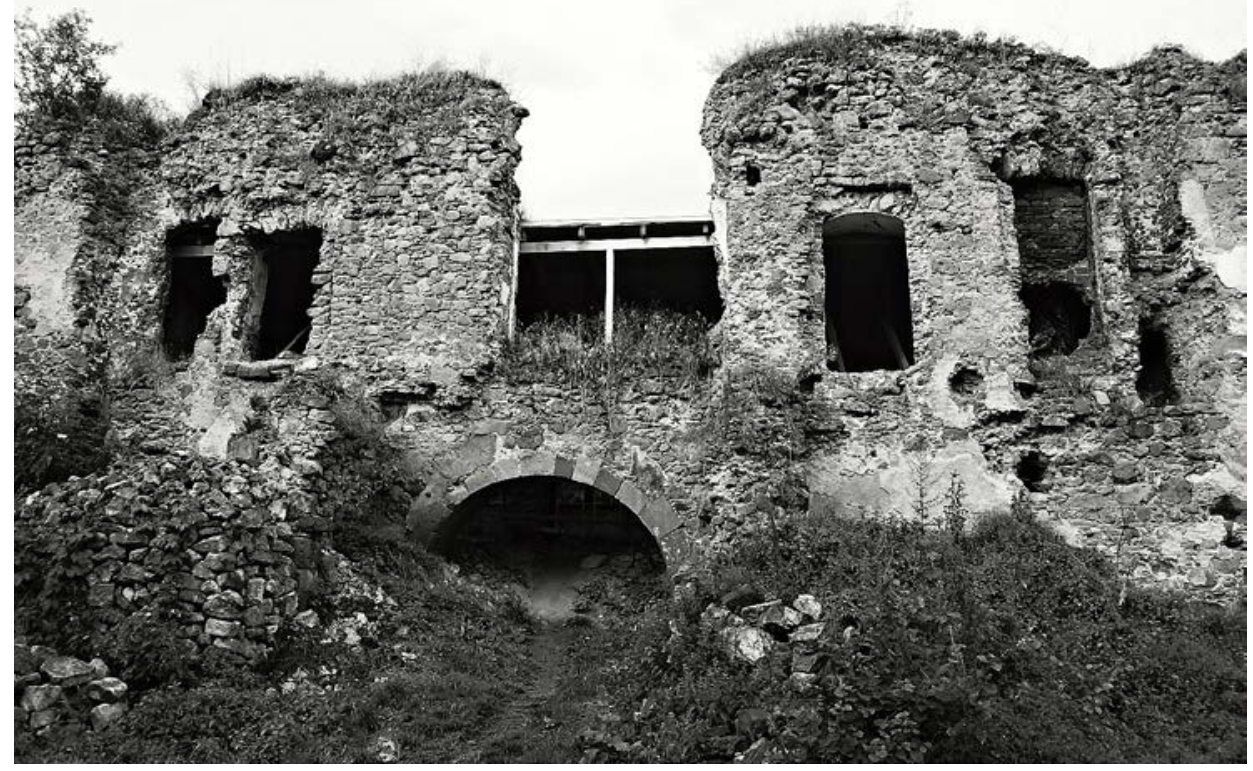

Obr. 19. Hrad Čabrad', okr. Krupina. Pohl’ad na západnú fasádu tretej brány z hradného nádvoria v roku 2015.

Foto M. Mordovin.

Abb. 19. Burg Čabrad', Bezirk Krupina. Blick auf die Westfassade des dritten Tores vom Burghof aus dem Jahr 2015.

Foto M. Mordovin. 


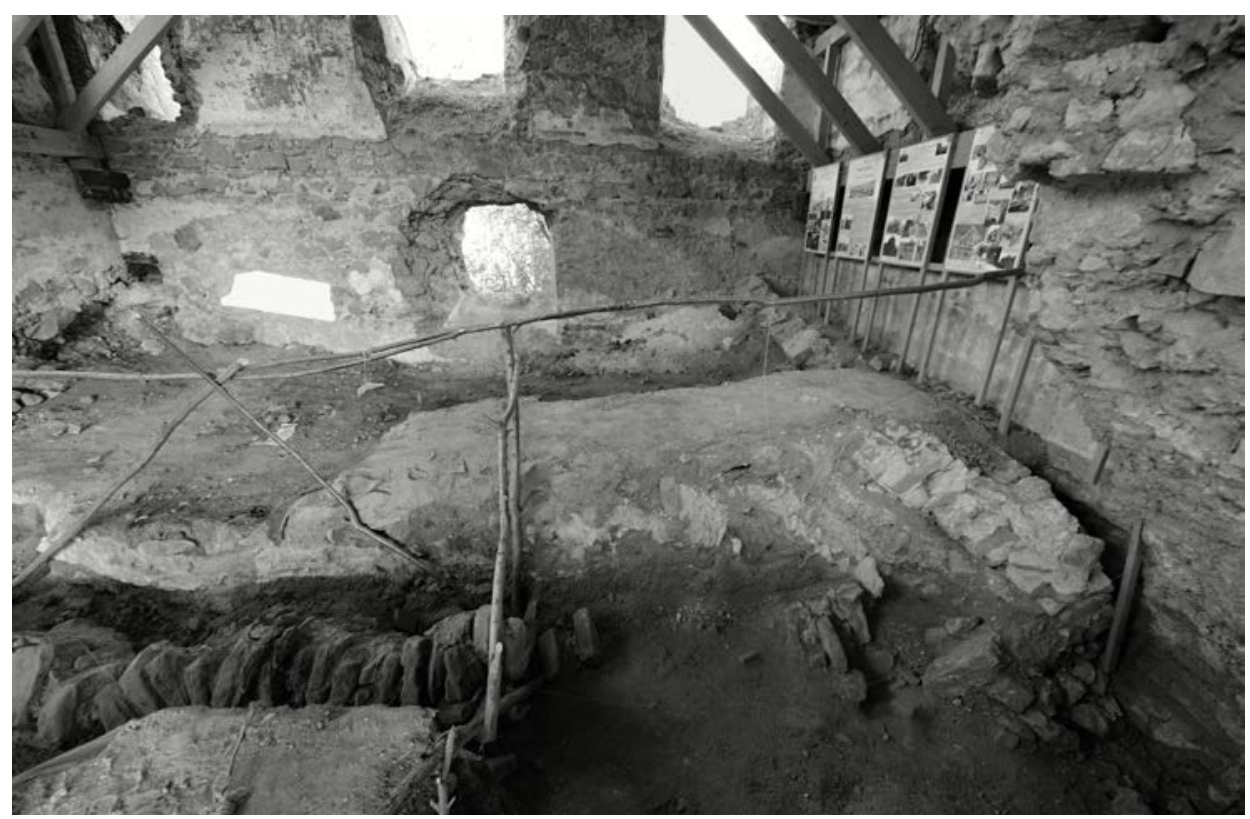

Obr. 20. Hrad Čabrad', okr. Krupina. Severná čast’ interiéru tretej brány na úrovni druhého podlažia po výskume v roku 2015. Foto J. Beljak.

Abb. 20. Burg Čabrad', Bezirk Krupina. Nördlicher Teil des Interieurs des dritten Tores in Höhe des zweiten Stockwerks nach der Grabung im Jahr 2015. Foto J. Beljak.

\section{Kachlice}

Počas troch sezón výskumu priekopy pred tret’ou bránou bolo objavených približne 3400 fragmentov kachlíc. Tento súbor tvorili neskororenesančné, habánske a barokové exempláre. Takmer všetky kachlice sú glazované, väčšinou zelenou alebo tmavozelenou glazúrou. Neskororenesančné a habánske kachlice obsahujú rastlinné motívy. Barokové sú glazované, ale bez ornamentálnej výzdoby. Glazovaný povrch barokových kachlíc je vytvorený kvapkovaním, ktoré napodobňuje mramorovanie. Tento druh kachlíc sa začína vyskytovat' pravdepodobne od záveru 17. storočia. Doložený je z vrstiev datovaných do 18. storočia z výskumov vo Filakove a v Sečanoch. Ojedinele sa vyskytuje aj v priebehu 19. storočia (Čurný-Pažinová 2010, 150).

Na výzdobu habánskych kachlíc sa použivala olovnato-ciničitá glazúra bielej, modrej a žltej farby. Reliéfnu výzdobu habánskych kachlíc dotvárali glazúrou odlišnou od pozadia: pri modrom pozadí používali bielu, pri bielej modrú a pri žltej modrú farbu. Nie všetky habánske kachlice boli reliéfne, často sa výzdoba robila aj pomocou kukučky.

Rôzne druhy renesančných a habánskych kachlíc sa distribuovali na väčšie územie. Analógie k niektorým renesančným kachliciam z Čabrade sa vyskytujú v Sečanoch, Fillakove, Krupine (Roganský 2007, 272, obr. 83/1-3), Lukáčovciach (Čurný 2004, tab. 57/50_002) a v Necpaloch (Samuel 2007, 276, obr. 87/5). Ďalšie nálezy podobné fragmentom kachlíc zdobených akantovitými lístkami sú známe z Lukáčoviec (Čurný 2004, tab. 57/44_006, 44_007, 44_008).

Medzi habánskymi kachlicami sa rozlišujú najmenej tri alebo štyri väčšie súbory. Pre jeden z takýchto súborov (podl’a ornamentu a farby) je najbližšia analógia známa z pôvodného kaštiel’a rodiny Baán z Trstenej. Pre iné súbory habánskych kachlíc z Čabrade nie sú známe presné analógie. Nepoznáme taký vel'ký súbor z ani jedného objektu. Zdá sa, že patria do vel'kej skupiny kachl'ových pecí z druhej polovice 17. storočia, vyrobených výslovne podl'a zákazky majitel'ov Čabradského hradu. 


\section{Keramika}

Najväčší a najviac reprezentatívny súbor keramiky sa objavil vo vrstvách priekopy pred tretou bránou. Súbor keramických nádob pozostáva z kuchynskej, ako aj zo stolovej keramiky. V súbore sú zastúpené nádoby vysokých (džbány, hrnce), ako aj širokých tvarov (taniere, misy, trojnožky). Celkovo môžme získané nálezy zhodnotit’ ako vyspelú a rutinne vyhotovenú, prevažne glazovanú keramiku dobrej kvality. Všetky hodnotené keramické exempláre boli vyhotovené na rýchlo rotujúcom hrnčiarskom kruhu. Povtrdzuje to aj ich tenkostennost'. Medzi čabradskou keramikou sa vyskytuje aj osobitná skupina miniatúrnych nádob, ktoré napodobňujú nádoby štandardných rozmerov. Sú v nej zastúpené takmer všetky tvarové a výzdobné riešenia.

Z hladiska použitia hliny, engóby a glazúry sú čabradské keramické nálezy vel’mi rôznorodé. Početne je zastúpená keramika z bežnej železitej hliny tehlovočervenej farby. V menšej miere sa vyskytujú hliny z ílov okrových farieb. Najmenšou je skupina tzv. gemersko-novohradskej keramiky, vyrobenej z bielych ílov.

Používali sa transparentné, ale aj nepriehl’adné glazúry zelených, žltých, hnedých a modrých farieb. Glazúrou sa pokrývala celá vnútorná čast' nádob všetkých širokých tvarov (mís, tanierov, trojnožiek), všetkých hrncov a niektorých džbánov. Väčšina džbánov bola glazovaná aj zvonku. Takmer vo všetkých prípadoch sa pod glazúrou nachádzali hnedé a biele engóby.

Pri nádobách širokých tvarov (najprv taniere a misy) bola výzdoba na vnútornej strane nádob rytá pod glazúrou do podkladovej engóby. Pri nádobách z bielych ílov bola zastúpená aj výzdoba mal'ovaná červenou farbou, umiestnená na rozhranie hrdla a pliec nádoby. Osobitnú skupinu keramických nálezov predstavujú nádoby tak vysokých, ako aj širokých tvarov s engóbovou výzdobou aplikovanou kukučkou pod glazúru. Skladá sa najčastejšie zo žltej, zelenej, niekedy červenej, hnedej a čiernej engóby alebo glazúry. Pri nádobách vysokých tvarov bola táto výzdoba umiestnená na plecia alebo plecia a hrdlo džbánov, prípadne krčahov.

\section{Široké tvary}

Široké tvary boli v nálezovom súbore zastúpené tanierovitými misami, taniermi, šálkami, pokrievkami a trojnožkami. Okraje nádob širokých tvarov boli jednoducho polgul'ovito zaoblené a vtiahnuté do vnútra nádob. Ojedinele sa vyskytuje aj slabo naznačené okružie.

\section{Taniere a misy}

Medzi nádobami širokých tvarov sú najpočetnejšie zastúpené taniere (obr. 21). Podla výzdoby patria taniere a ploché misy z priekopy do šiestich typologických skupín. Celkovo je v súbore nádob širokých tvarov zretel’ná mierna dominancia zdobených nádob nad nezdobenými.

Prvá skupina je najpočetnejšia a obsahuje iba nezdobené glazované nádoby. Používali sa priehl’adné glazúry nanesené priamo na povrch, ale aj zelené a žlté glazúry nanesené na bielu engóbu. Takéto taniere sa vyrábali už od 16.-17. storočia a doložené sú aj v 18. storočí. Charakteristickým prvkom čabradských nálezov sú polgul'ovito alebo trojuholníkovito zosilnené okraje.

Vel'a analógií $\mathrm{k}$ tomuto typu nádob pochádza $\mathrm{z}$ archeologického výskumu kaštiel'a $\mathrm{v}$ Lukáčovciach (Čurný 2004). Tento vel’mi jednoduchý druh keramiky sa však vyskytuje takmer na všetkých novovekých náleziskách.

Druhú skupinu reprezentujú exempláre s tzv. kvapkanou výzdobou, ktorá vznikla používaním engôb alebo glazúr rôznych farieb. Kvapkanie sa najčastejšie robilo svetlozelenou glazúrou na tmavozelenej glazúre. Zriedkavejšie sa vyskytujú nádoby s kvapkaním hnedou glazúrou. Podobne zdobené boli misy, kde sa kvapkanie robilo zelenou a hnedou glazúrou na bielej engóbe. Nálezy tohto typu sú známe z územia Rakúska už od prvej polovice 17. storočia (Harl b. r., 166, obr. 263; 167, obr. 266). V Uhorsku sa objavujú počas osmanskej okupácie. V severných regiónoch Uhorska sa rozšírili od polovice 17. storočia (v niektorých územiach asi až od 18. storočia). Najbližšie analógie sa vyskytujú medzi nálezmi z budínskej hrnčiarskej dielne z 18. storočia (Benda 2007, 307, obr. 6). Ďalšie podobné nálezy boli nájdené v Lukáčovciach (Čurný 2004, tab. 9/17_059; tab. 33/19_158). Vzdialenejšie analógie sa vyskytujú v Stropkove v súbore datovanom mincou do 18. storočia (Kotorová-Jenčová 2006, 216, obr. 51/4). 


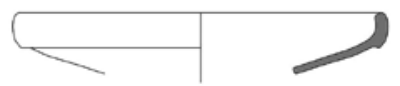

I.
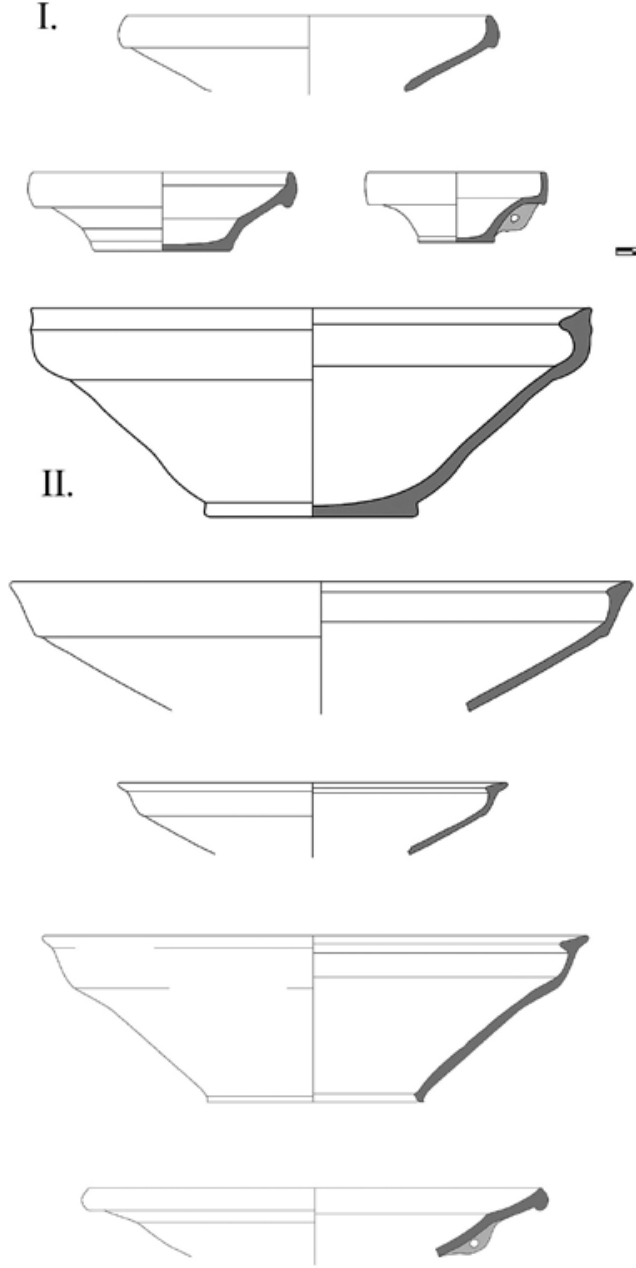

V.
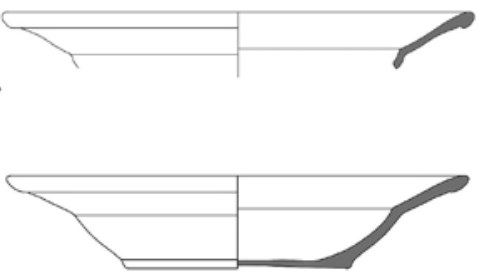

VI.
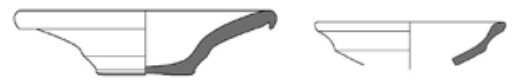
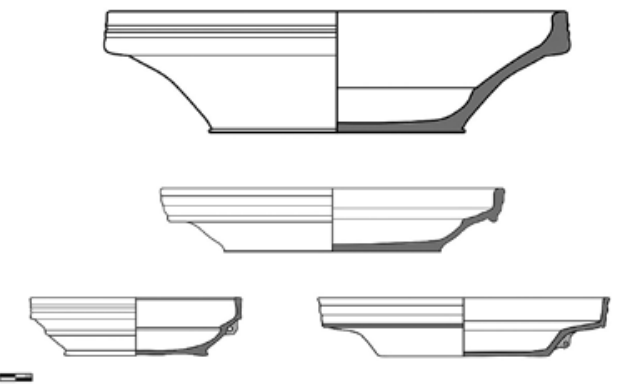

III.
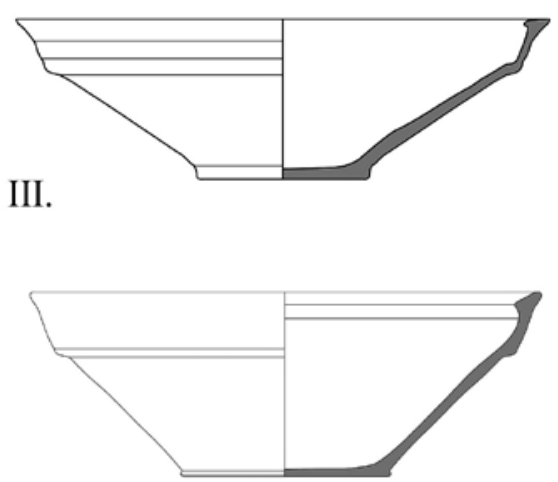

IV.
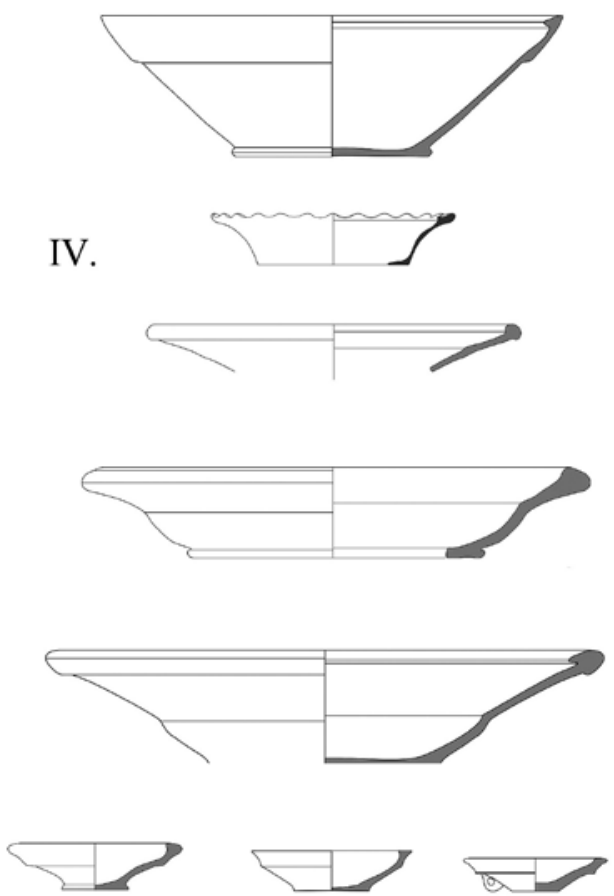

Obr. 21. Hrad Čabrad', okr. Krupina. Výber keramických nálezov z výskumu v rokoch 2013-2015. Kresba M. Mordovin. Abb. 21. Burg Čabrad', Bezirk Krupina. Auswahl an Keramikfunden von der Grabung 2013-2015. Zeichnung M. Mordovin. 
Do tejto skupiny môžeme zaradit’ aj súbor nádob s výzdobou, ktorú tvorili svetlé odtlačky zelenej glazúry aplikované končekom prsta na bielu podkladovú engóbu. Z takých odtlačkov sa skladali rôzne motívy, napríklad hviezdy, kvety atd'.

Tretia skupina nádob bola zdobená vyspelejšou výzdobnou technikou. Pomocou rôznofarebných engôb a glazúr sa robil tzv. ,polievaný“ ornament. Výzdoba sa robila vylievaním bielej engóby priamo na červený črep alebo tmavej glazúry na povrch bielej (svetlej) engóby. Tvorili sa tým nepravidelné a radiálne situované zvislé pásy. Na ňu bola ešte nanesená prehl'adná glazúra. Takmer všetky fragmenty nádob z hradu Čabrad' patriace do tejto skupiny boli súčasne zdobené zelenou a hnedou glazúrou na povrchu bielej engóby. Podobné keramické fragmenty sa objavili v Lukáčovciach (Čurný 2004, tab. 5/17_007). Takéto taniere sa vyskytovali tiež medzi nálezmi budínskej dielne (Benda 2007, 307, obr. 7).

Štvrtú skupinu tvoria nádoby s najpoužívanejším spôsobom zdobenia na fragmentoch z Čabrade. Charakteristické bolo jednoduchým rytím do črepu alebo do engóby pod prehladnou glazúrou. Tento typ výzdoby sa začal používat' na keramike z bielych ílov v gemersko-novohradskom regióne už na konci 16. storočia. Na území dnešnej Budapešti sa takto zdobené taniere z gemersko-novohradských dielní vyskytujú od začiatku 17. storočia (Bertalan 1998, 216-217, II-III. t.; 227, XXVI. t.). Spočiatku neboli glazované. Prvé glazované príklady s rytou výzdobou sa objavujú v prvej tretine 17. storočia. Doložené sú v súboroch z Fil'akova a Sečian (Kalmár 1959, LXVIII, LXX). Ich výzdobu tvoril široký pás mal'ovaný červenou engóbou. Na hornej vnútornej časti tanierov bol povrch preškrabaný hrebeňovitým nástrojom do bieleho črepu. Následne sa celý vnútorný povrch taniera pokrýval prehl'adnou glazúrou žltej farby. Všetky čabradské nálezy štvrtej skupiny boli vyrobené z červených ílov a ich výzdoba bola rytá do bielej engóby. Glazúry boli priehl'adné. Zriedkavo sa vyskytujú aj zelenoglazované taniere. Rytá výzdoba na tanieroch sa najčastejšie robila na ich vnútornej hornej časti. Niektoré druhy, ktoré mali široké, ploché, takmer horizontálne okraje, boli zdobené aj vlnovkou na okrajoch.

Početné taniere s rytou výzdobou sú známe z lukáčovského kaštiel’a (Čurný 2004, tab.3/11_004; tab.5/17_017; tab. 8/17_058, 17_060; tab.9/17_050, 17_054, 17_063; tab. 20/5_065). Najbližšie analógie k čabradským tanierom sú známe z už spomenutej budínskej dielne (Benda 2007, 307, obr. 8).

Najvyspelejší druh výzdoby reprezentuje piata skupina, ktorú tvoria nádoby zdobené technikou kukučkovania. Táto technika výzdoby sa objavila v druhej polovici 16. storočia. Do Uhorska prišla z Rakúska alebo z Moravy (Kubín 2005, 94-95). Vo Viedni sa takto zdobené taniere vyskytujú už od začiatku 17. storočia (Harl b. r., 170-171, 174-176). Na území Uhorska sa dobre datované nádoby zdobené pomocou kukučky objavili počas výskumu na hrade Bajcsa. Ten zanikol na samom začiatku 17. storočia (Kovács 2002, 65-66, 208-210). V Starom Budíne sa takto zdobené taniere vyskytujú od začiatku 17. storočia. Zastúpené sú nádoby z bielej a červenej hliny (Bertalan 1998, 216-217, I. t., IV. t.). Vel'ké množstvo typologicky rôznorodých nádob zdobených metódou „kukučkovania“ pochádza z Filakovského hradu. Datované sú do záveru 17. storočia (Kalmár 1959, LXVII-LXVIII, LXXIII). V súbore nálezov z Čabrade sú zastúpené obe technologické riešenia tejto výzdoby: mal'ovanie pomocou kukučky bielou a čiernou engóbou priamo na povrch nádoby červeného črepu a aj zložitejšia technika nanášania červenej, žltej, zelenej a tmavohnedej (čiernou) engóby na podkladovú bielu engóbu.

V Lukáčovciach sa objavilo len niekol'ko takých nálezov, ale s iným ornamentom (Čurný 2004, tab. 6/17_064; tab. 18/5-062). Kukučkované taniere, dobre datovatel'né do 18. storočia, ale s odlišnou kompozíciou sú známe zo Stropkova (Kotorová-Jenčová 2006, 216, obr. 51/2; 218, obr. 52/1-4) a Necpal (Samuel 2007, 277, obr. 88/6). Kukučkované nádoby (taniere a misy) sa vyskytovali ešte aj v 19. storočí a sú ešte súčast'ou l'udového umenia (Čurný-Pažinová 2010, 155, obr. 3/8, 10-11; 156, obr. 4/4, 7-8).

Šiesta skupina sa skladá z nádob so zložitou malovanou výzdobou. Od piatej skupiny sa odlišuje tým, že pri zhotovení výzdoby nepoužívali kukučku. Všetky ornamenty boli mal'ované širokými pásmi. Malovanie sa zriedkavo vyskytovalo aj na tanieroch zdobených pomocou kukučky. Pre zložitejšiu kompozíciu používali tmavú (tmavohnedú alebo čiernu) engóbu. Výzdoba 
sa mal'ovala červenou, žltou a zelenou farbou, s bielymi obrysmi robenými kukučkou. Bielou farbou sa na podkladovú čiernu engóbu kreslili aj lupienky a listy vegetabilných kompozícií. V niektorých prípadoch sa podkladovou tmavou engóbou pokrývala len horná vnútorná čast' tanierov. Vtedy sa horná čast' zdobila bielou, zelenou a dno čiernou a bielou farbou. Vel'mi oblúbenou grafickou kompozíciou v 18. storočí boli centrálne situované kvetinové motívy pokrývajúce väčšinu plochy nádob. Potvrdzujú to aj keramické fragmenty objavené počas výskumu na hrade Čabrad'. Najbližšie analógie k nim sú známe z budínskej keramickej dielne (Benda 2007, 307, obr. 7).

Medzi keramickými nálezmi z hradu Čabrad' sa objavuje aj kombinácia niekol'kých už spomenutých spôsobov zdobenia. Najčastejšie je to spoločná aplikácia rytej a kukučkovej výzdoby. Známe sú aj fragmenty tanierov s mal'ovanou, rytou a kukučkovou výzdobou. Predpokladáme, že tieto nádoby boli v 18. storočí pomerne drahé. Patrili do skupiny stolovej keramiky, ktorá sa vyskytovala v šlachtickom prostredí a nenachádzame ju v pol’nohospodárskych osadách.

\section{Trojnožky}

Do súboru širokých tvarov patria aj trojnožky, ktoré sú početne zastúpené medzi nálezmi z výskumu na hrade Čabrad' (obr. 22/I-II). Rozlišujú sa dve tvarové skupiny. Prvá pozostáva z trojnožiek s rovným dnom a nízkymi okrajmi. Nádoby druhej skupiny majú oblé dná a vysoké steny so širokými, polgul'ovito zaoblenými okrajmi.

Tento druh nádob sa vyskytuje už od druhej polovice 13. až do začiatku 14. storočia (Harl b. r. 63). Početnejšie sa využíva až od 16., resp. 17. storočia. Jeho početné zastúpenie je v jednotlivých regiónoch Uhorska odlišné. Podl’a nálezov zo Sečian, Fillakova (Kalmár 1959, LXXVII), Drégel'u a Čabrade sa trojnožky v hontiansko-novohradskom regióne vo väčšom množstve objavujú až od 18. storočia.

Všetky čabradské trojnožky sú glazované. Najčastejšie zelenou alebo v menšej miere hnedou farbou. Niekol'ko exemplárov má vnútorný povrch pokrytý priehl'adnou glazúrou bez podkladovej engóby. Vyrobené sú z červených a žltých ílov. Trojnožky vieme datovat' podla tvarov ich okrajov a nožičiek. Čabradské nálezy najčastejšie reprezentujú exempláre s vysokými rovnými stenami a vyhnutým, v niektorých prípadoch takmer horizontálnym okrajom. Ústia čabradských nálezov sú silne vyhnuté s charakteristickými zaoblenými okrajmi. Medzi nálezmi z Čabrade je potvrdených iba niekol'ko držadiel z trojnožiek. Mali zväčša valcovitý tvar. Pre nálezy z 18. storočia sú typické zahĺbenia pod dnami nádob, na hornej vonkajšej strane nožičiek. Ešte mladším prvkom sú špirálovito vykrútené konce nožičiek, ktoré sú potvrdené aj v skúmanom keramickom súbore.

Fragmenty nožičiek so zahíbeniami na hornej časti sa vyskytujú v Lukáčovciach (Čurný 2004, tab. 4/11_41; tab. 47/13_060). Vel'mi podobné okraje sú charakteristické pre trojnožky z budínskej dielne (Benda 2007, 309, obr. 14).

\section{Vysoké tvary}

V keramickom súbore z výskumu tretej brány hradu Čabrad' dominujú nádoby vysokých tvarov. Dná majú mierne konkávne a náznakovo odsadené. Často sú na nich viditel’né stopy po doske hrnčiarskeho kruhu. Všetky typy nádob (hrnce, džbány a krčahy) mali pásikové uchá v priereze s pretiahnutým oválnym alebo elipsovitým tvarom.

\section{Hrnce}

Najpočetnejšie zastúpené typy nádob tvoria hrnce (obr. 23). Počas výskumu na hrade Čabrad' boli objavené exempláre so štyrmi typmi okrajov: 1) ústia vyhnuté so strechovite zrezanými okrajmi a okružím; 2) ústia s výrazne vysokým, odsadeným a zvonku viackrát žliabkovaným zdobeným okružím; 3) vyhnuté ústia s výrazne vysokým okružím a jednoducho zaoblenými okrajmi; 4) vyhnuté ústia mierne zalomené, okružie je drobnejšie ovalené a zdobené jednou horizontálnou ryhou. V súbore sú zastúpené nádoby červenej, červenožltej a žltej hliny. Väčšina nálezov hrncov z priekopy je glazovaných. Glazúry sú rôznych farieb. Najčastejšie sú zelené a hnedé. Menej početne zastúpené sú tmavohnedé a priehl'adné. Hrnce majú zdobené najčastej- 

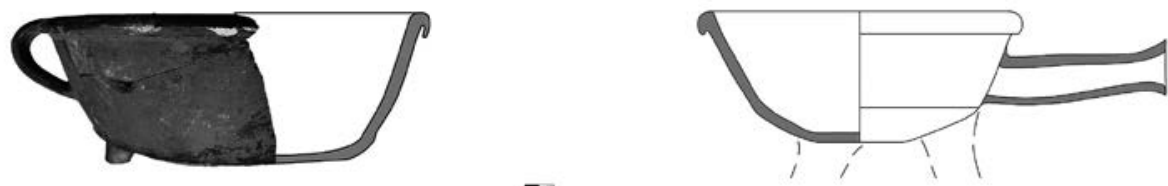

I.
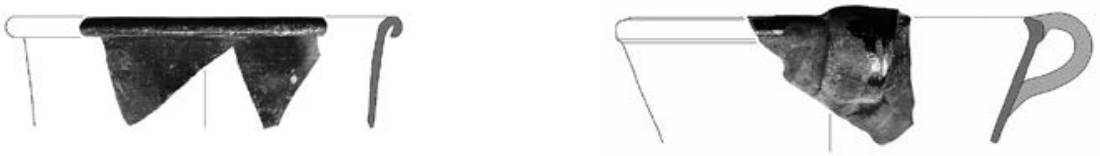

II.
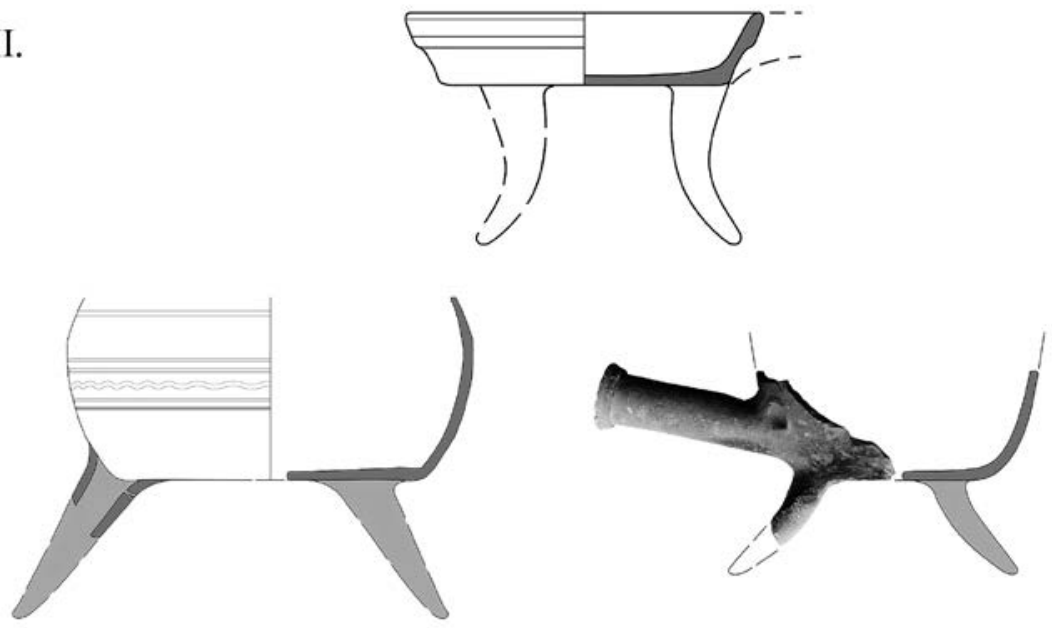

III.
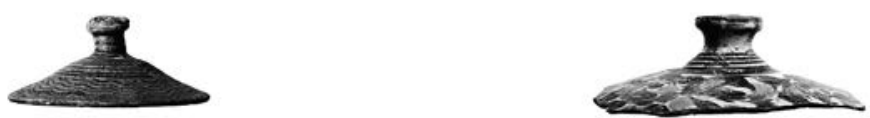

Obr. 22. Hrad Čabrad', okr. Krupina. Výber keramických nálezov z výskumu v rokoch 2013-2015. Kresba M. Mordovin. Abb. 22. Burg Čabrad', Bezirk Krupina. Auswahl an Keramikfunden von der Grabung 2013-2015. Zeichnung M. Mordovin.

šie plece a hrdlo vodorovným rytým žliabkovaním. Iným riešením ich výzdoby bolo zdobenie vonkajšej strany červenou alebo bielou engóbou. Pri týchto prípadoch sa výzdoba skladala z mal’ovaných vodorovných pásov. Niekedy bola doplnená rytím alebo vlnovkou.

Najbližšie analógie hrncov s jednoduchým profilovaným okrajom a rytou výzdobou poznáme z Krupiny (Roganský 2006, 235, obr. 73/12; 2007, 272, obr. 83/4-5). Tam boli objavené aj hrnce zdobené zvonku červenými vodorovnými pásmi (Roganský 2007, 272, obr. 83/12). Vel'mi podobne profilované okraje hrncov sa našli aj v Nitre vo vrstvách pochádzajúcich pravdepodobne z 18. storočia (Samuel 2005, 277, obr. 94/2-3; 2006, 243, obr. 83/13). Ďalšie analógie poznáme z Nových Zámkov z výplne hradnej priekopy, ktoré sú datované do prvej polovice 18. storočia (Kovácsová 2004, 117, 264, obr. 54/9, 14). Tvarom a výzdobou takmer rovnaké nálezy poznáme z Panenskej ulice v Bratislave. Súbor keramiky sa tu objavil pri evanjelickom kostole postavenom v roku 1777 (Baxa 1978, 40, 293, obr. 12/4, 6-7). 
Podobne jednoducho riešené okraje s rytou výzdobou na vonkajšej strane majú hrnce z Lukáčoviec (Čurný 2004, tab. 4/11_042; tab. 15/5_058, 5_064; tab. 16/5_044; tab. 21/44_060; tab. 48/13_100,13_107; tab. 51/13_102 atd’.). Rovnaké typy okrajov hrncov sú známe z Borovíc, zo súboru datovaného do 18.-19. storočia (Čurný-Kopčeková 2001, 39; 238, obr. 13/2-3; 239, obr. 14/1). Na území Komárna sú hrnce s jednoduchým okrajom a rytou vodorovnou výzdobou na vonkajšej strane potvrdené aj v 19. storočí (Čurný-Pažinová 2010, 157, obr. 5/8). Hrnce s podobne profilovaným okrajom sa našli aj v Necpaloch (Samuel 2007, 277, obr. 88/1-5).

Rovnako vyhnuté ústia so strechovito zrezanými okrajmi sú doložené aj na hrncoch z budínskej dielne (Benda 2007, 309, obr. 17) a medzi nálezmi z krčmy z 18. storočia, skúmanej v Székesfehérvári (Siklósi 2002, 60-73). V regiónoch južne od Budína sa síce podobné profilácie okrajov hrncov vyskytujú, ale ich celkové tvary sú už odlišné od nálezov z hradu Čabrad' (Vizi 2010, 824-825, obr. 4-5).

\section{Džbány a krčahy}

Je zaujímavé, že výskumom bolo odkryté iba malé množstvo nádob tohto druhu. Determinoval to snád' charakter skúmaného objektu a môžeme ho interpretovat' prítomnostou kuchyne. V tej sa používalo viac hrncov, mís a tanierov. V menšej miere využívali stolovú keramiku, ktorú tvorili džbány, krčahy a poháre (z výskumu na hrade Čabrad' nemáme zatial' doložený žiaden fragment keramických pohárov). Objavené džbány a krčahy však patria medzi luxusnú, bohato zdobenú keramiku (obr. 24/I-III). Celkovo sa výskumom podarilo potvrdit’ šest' základných druhov džbánov a krčahov. Najviac fragmentov pochádza z nádob vyrobených z červenej hliny. Do tejto skupiny patria štyri rôzne druhy nádob. Najjednoduchšie reprezentujú neglazované džbány zdobené geometrickým mal'ovaním bielou engóbou a dodatočným preškrabaním. Vyskytujú sa tiež nálezy bez podkladovej engóby, ktoré sú iba glazované zelenou alebo prehl'adnou glazúrou a s kukučkovou výzdobou. Najpočetnejšie sú zastúpené keramické fragmenty vyrobené z červených ílov, ktoré majú na povrchu engóbu aj glazúru. Používala sa biela a tmavohnedá farba engóby. Väčšina nádob s bielou engóbou bola pokrytá priehladnou glazúrou. V niektorých prípadoch mala vnútorná strana prehl’adnú a vonkajšia strana zelenú glazúru. Vyskytujú sa aj džbánky, ktorých výzdoba bola doplnená kvapkovaním. Najvyspelejšiu skupinu nádob vyrobených z červenej hliny reprezentujú exempláre s hnedou alebo tmavohnedou glazúrou na bielom engóbovom podklade. Na ne bola bielou farbou pomocou kukučky nanesená zložitá vegetabilná výzdoba, doplnená o mal’ovanie zelenou a červenou farbou. Takto zdobené džbány boli objavené aj počas výskumu v Nitre (Samuel 2006, 244, obr. 84/1).

Najmenej početnú skupinu tvoria nádoby vyrobené z bielej hliny. Reprezentujú tzv. gemersko-novohradskú keramiku druhej polovice 17. storočia. Analógie poznáme z hradov Fil’akovo (Kalmár 1959, LXXIII), Sečany, z Modrého Kameňa a pod. V blízkom okolí Čabrade sa biela keramika v 17.-18. storočí nevyrábala. Z archívnych prameňov však vieme, že gemerskú keramiku jej výrobcovia distribuovali do vel'kých vzdialeností (Havassy 2003, 424-425). Takto sa tieto nádoby pravdepodobne dostali aj na hrad Čabrad'. Sú to najstaršie nálezy z celého súboru keramiky z výskumu priekopy pred tret’ou bránou.

Nádoby z bielej hliny mohli byt' neglazované alebo iba mal'ované červenou engóbou. Väčšina z nich však bola zdobená zelenou glazúrou bez podkladovej engóby. Niektoré boli dodatočne dozdobené pásmi mal’ovanými červenou engóbou. Dve nádoby reprezentujú špecifický typ džbánov s tzv. filtračnou vložkou, ktorý sa začal vyrábat' na konci 16. storočia. Blízke analógie k týmto džbánom sa objavili na Mostnej ulici v Nitre (Samuel 2005, 277, obr. 94/5, 9; 2006, 244, obr. 84/1).

Vel'mi zriedkavo sa na Čabradi vyskytoval druh tzv. novovekej šedej keramiky (zhotovenej redukčným výpalom). Táto sa objavuje až v závere 16., resp. na začiatku 17. storočia. Do tejto skupiny patria výlučne nádoby na prechovávanie kvapalín (džbány a krčahy). Podobne je to s nálezmi tzv. čiernej keramiky, ktorej povrch bol pred vypálením upravený vleštovaním. Analogické novoveké redukčne vypálené fl'aše z 18.-19. storočia poznáme napr. z Komárna (Čurný-Pažinová 2010, 147, 155, obr. 3/3, 6). 

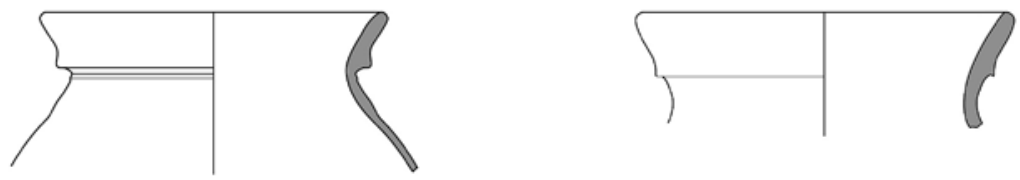

I.
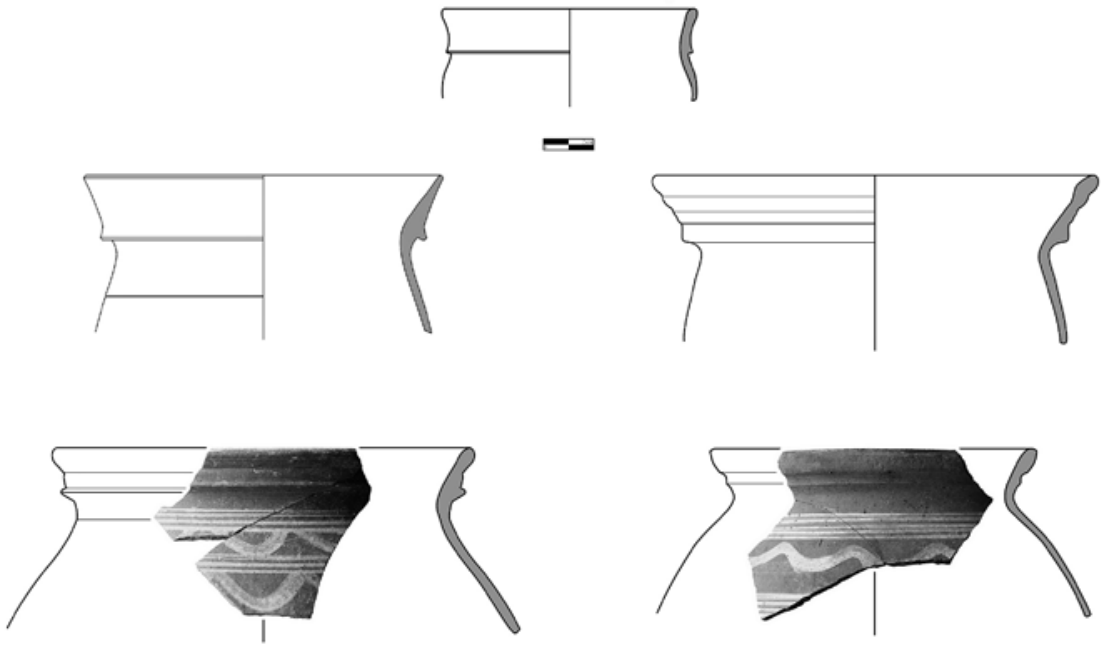

II.
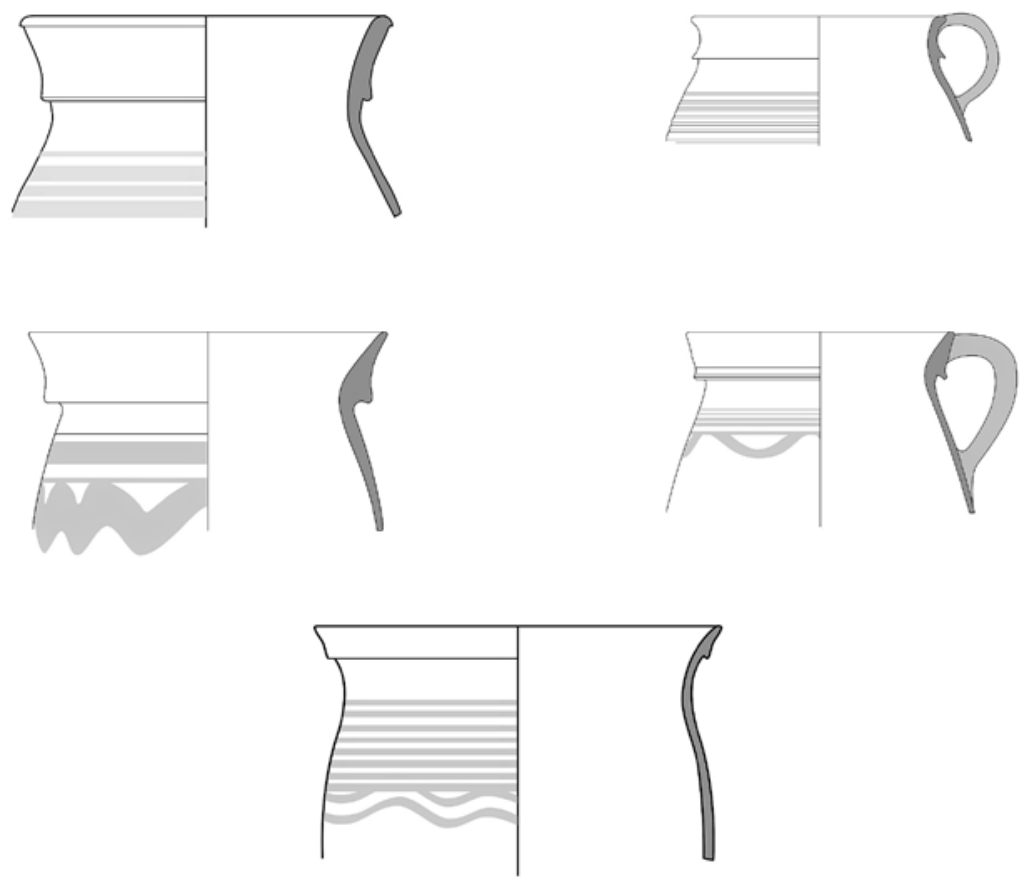

Obr. 23. Hrad Čabrad', okr. Krupina. Výber keramických nálezov z výskumu v rokoch 2013-2015. Kresba M. Mordovin. Abb. 23. Burg Čabrad', Bezirk Krupina. Auswahl an Keramikfunden von der Grabung 2013-2015. Zeichnung M. Mordovin. 

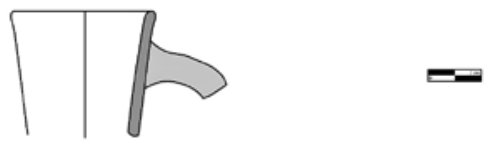

I.

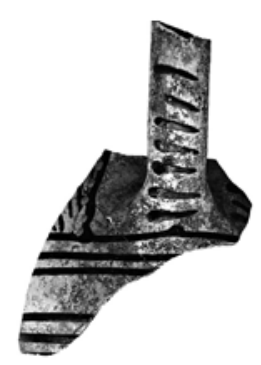

II.
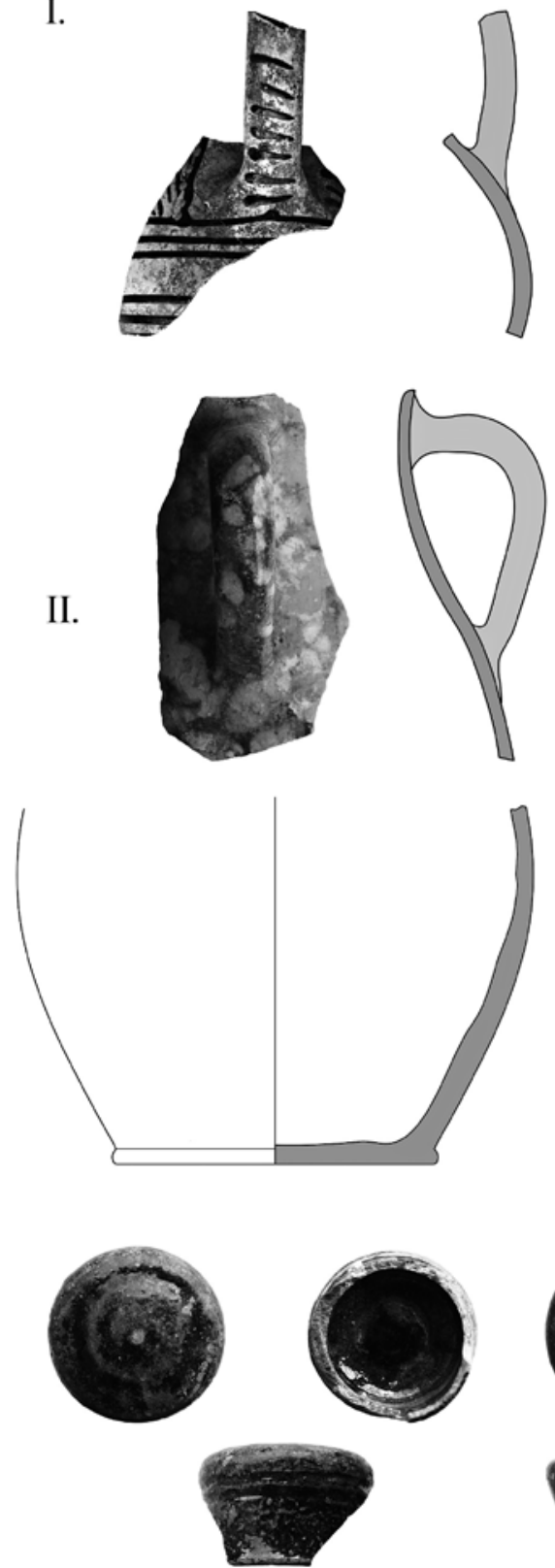
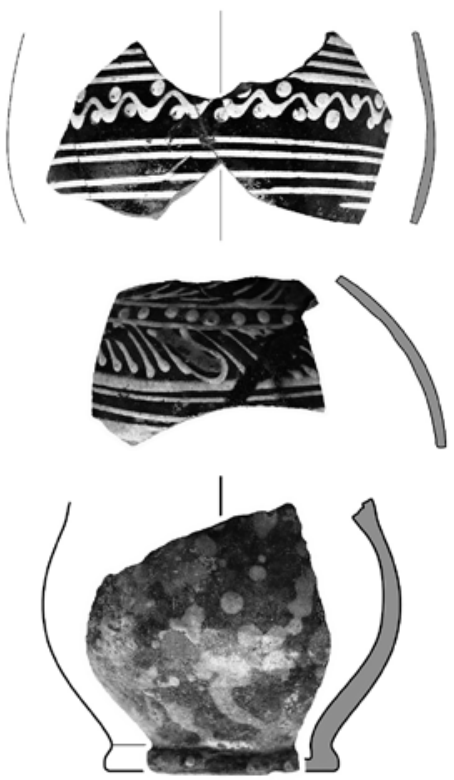

III.
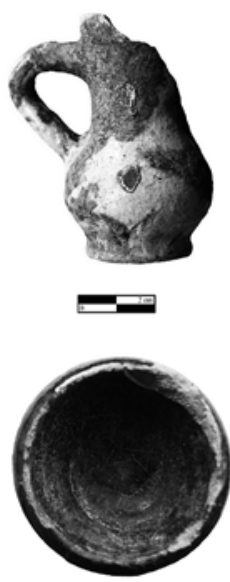

IV.
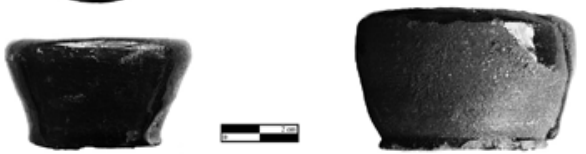

Obr. 24. Hrad Čabrad', okr. Krupina. Výber keramických nálezov z výskumu v rokoch 2013-2015. Kresba M. Mordovin. Abb. 24. Burg Čabrad', Bezirk Krupina. Auswahl an Keramikfunden von der Grabung 2013-2015. Zeichnung M. Mordovin. 


\section{Pokrievky}

Pri skúmaní priekopy pred tretou bránou sa objavilo viacero fragmentov pokrievok (obr. 22/III). Podl’a ich výzdoby rozlišujeme tri základné skupiny: 1) jednoducho glazované (sem patrí jedna z „miniatúrnych“ nádob objavených v roku 2014); 2) glazované s rytou výzdobou; 3) glazované mal'ované. Kónicky tvarované pokrievky sú ukončené gombíkovitým držadlom. Glazované nezdobené pokrievky sa vyskytujú už od 17. storočia (Fil'akovo: Kalmár 1959, LXXVI). Potvrdené sú aj z výskumu budínskej hrnčiarskej dielne (Benda 2007, 308, obr. 10). Pokrievky podobných tvarov ako z výskumu priekopy na hrade Čabrad' sú známe z vrstiev z 18.-19. storočia z Komárna (Čurný-Pažinová 2010, 146, 155, obr. 3/5; 156, obr. 4/1-2; 157, obr. 5/5).

\section{Habánska keramika}

V súbore keramiky z výskumu na Čabradi je početne zastúpená aj habánska keramika. Vzhl'adom k fragmentárnosti jej úlomkov je ich tvarová rekonštrukcia zatial' pomerne náročná. Objavujú sa šálky, dvojuché šálky, taniere, fl’aše, džbány, krčahy. Pomer zastúpenia širokých a vysokých tvarov je približne rovnaký. Väčšina exemplárov vysokých tvarov patrí do skupiny džbánov gul'ovitých foriem. Na žiadnom z keramických úlomkov sme nenašli kompletne zachovaný rok výroby. Na jednom črepe z modro glazovaného taniera sa zachovalo číslo „37“. Na základe stratigrafického vyhodnotenia nálezovej situácie predpokladáme, že ide o rok [16]37. Menej pravdepodobný je rok [17]37.

Všetky objavené fragmenty habánskej keramiky boli vyrobené zo žltých alebo svetlých ílov. Zdobené boli bielou alebo modrou olovnato-ciničitou glazúrou na vnútornej alebo vonkajšej strane. Na väčšine objavených fragmentov sa zachovala mal'ovaná výzdoba s prevahou vegetabilných motívov.

Analógie $\mathrm{k}$ nájdeným habánskym džbánom z 18. storočia poznáme predovšetkým z múzejných zbierok (napríklad Umeleckopriemyselné múzeum v Budapešti). Jeden podobne bohato zdobený džbán s letopočtom pod uchom bol objavený na hrade Branč ( ̌̌íha 1980, 261, 449, obr. 153/4).

\section{Technická keramika}

Medzi širokými tvarmi sa v skupine malých nádob vyskytuje súbor glazovaných téglikov (obr. 24/IV). Majú analógie v baníckom prostredí v Banskej Štiavnici. Stopy druhotne roztavenej glazúry potvrdzujú, že aj na Čabradi sa používali pre svoj primárny ciel' - skúšanie rúd.

\section{Fajky}

Počas archeologického výskumu na hrade Čabrad' boli objavené keramické fragmenty z približne 30 exemplárov keramických fajok. Väčšina z nich je pre podrobnejšiu analýzu vel'mi fragmentárna. Niektoré sú však dobre zachované s čitatel'ným nápisom. Jedna z takýchto fajok pochádza zo Sv. Antona. Takmer všetky nálezy fajok z Čabrade sú vyrobené z červenej hliny a nie sú glazované. Iba jeden fragment fajky bol vyrobený z bielej hliny. Podobné fajky vyrobené z červenej hliny na Čabradi sú známe z výskumov v Nitre (Ruttkay 2004, 167, 301, obr. 96; Bielich-Čurný 2009, 341, fig. 3/e; 342, fig. 4/a, i - podobné: tab. 104/6 a tab. 104/1, 10) a Košiciach (Bielich-Šimčík-Čurný 2013, 86, obr. 1/7, 93 - podobné: tab. 104/6 a tab. 104/10). Fragment fajky vyrobený z bielej hliny má pomerne vernú analógiu z Nitry (Bielich-Čurný 2009, 342, fig. 4/j). Všetky spomínané nálezy z Nitry a Košíc sú datované do 18. storočia. Niektoré fajky z Čabrade (tab. 104/4, 9, 11) sú podobné nálezom z Komárna, ale tie sú o čosi mladšie (Čurný-Pažinová 2010, 148-149, obr. 2/4). 
V skúmaných sondách v tretej bráne sa objavilo aj väčšie množstvo sklených nálezov. Sú to predovšetkým fragmenty z rôznych pohárov a fliaš, ale objavili sa aj sklenené gombíky, fragmenty kríglov a okenné sklo.

Podl’a kvality, farby a stavu zachovania sklenené úlomky pochádzajú z rôznych sklární. Je pravdepodobné, že aj z niekol'kých krajín alebo regiónov. Priemerná kvalita objavených fragmentov však poukazuje na miestny pôvod väčšiny sklených predmetov z priekopy, a to predovšetkým okenného skla. Je pravdepodobné, že sklo pre výplne okien na budovách hradu bolo vyrobené $\mathrm{v}$ dielňach patriacich čabradskému panstvu, ktoré sa nachádzali $\mathrm{v}$ jeho blízkosti. $\mathrm{Z}$ vrstiev z 18.-19. storočia $\mathrm{v}$ priekope a $\mathrm{v}$ interiéri brány pochádzajú výlučne šest'uholníkové články okenných tabúl'. Je zrejmé, že okenné rámy brány boli v 18. storočí zasklené klátovými tabul'ami. Len z výplne spadnutých klenieb v jej vnútri je doložených niekol'ko fragmentov okrúhlych diskov datovatných najneskôr do záveru 16. storočia.

Medzi sklenými fragmentmi sa objavilo aj niekol'ko úlomkov z luxusných nádob. Boli vyrobené z nepriehl'adného bieleho alebo modrého skla a dodatočne zdobené mal’ovaným rastlinným ornamentom alebo pozlátením. Pravdepodobne pochádzajú z dielní v Benátkach a Murane.

\section{Kostené a parohové predmety}

Vrstvy z 18. storočia v priekope pred južnou fasádou tretej brány obsahovali aj mnoho kostených a parohových predmetov. Väčšinu týchto nálezov predstavujú jednoduché gombíky s rozmerom 0,6 až $1,2 \mathrm{~cm}$. Niekol'ko d'alších predmetov je možné identifikovat' ako malé hudobné nástroje alebo píštalky. Boli vyrobené z dlhších kostí a majú iba jeden malý otvor. Použivali sa pravdepodobne ako hračky.

Medzi parohovými nálezmi je zastúpený vel'ký dvojstranný hrebeň, ktorý neobsahoval žiadnu výzdobu.

Ojedinelými nálezmi z priekopy sú miniatúrne výrobky z mušle. Povrch týchto exemplárov je bohato zdobený rytým rastlinným ornamentom. Celkovo sa ich objavilo minimálne desat'. Podl'a rozmerov boli pravdepodobne súčastou intarzie rúčky rôznych príborov. Využitie mušle pre intarziu predmetov bolo na území Uhorska charakteristické pre habánske výroby od 17. storočia.

\section{Kovové nálezy}

Počas troch rokov výskumov v priekope pri tretej bráne sa objavilo vel'ké množstvo kovových nálezov datovaných do 18. storočia. Väčšinu zo železných predmetov tvorili klince, ale vyskytli sa aj ostrohy, podkovy, kovania z dverí, hroty striel, kl'úče, kresadlá, nože, vidličky a pod. Menej bolo nájdených výrobkov z farebných kovov - z bronzu, olova a striebra. Reprezentujú ich predovšetkým odevné ozdoby, napr. pracky a gombíky. V priekope pred tretou bránou sa objavilo aj niekol'ko olovených predmetov (gul'ky do pušky). K vzácnejším nálezom patria strieborné pracky, zlatý drôtik a bronzové prstene. Väčšina prsteňov z Čabrade má jednoduchý tvar totožný so súdobou barokovou módou. Jeden z prsteňov je však výnimočný (obr. 25/2). Na jeho štítku je monogram P.A. a erb pisára (ruka držiaca pero a kalamár). Zaujímavú skupinu predmetov z farebných kovov tvoria pútnické známky. Niektoré z nich určite pochádzajú z Mariazellu. Jedna zobrazuje Božie oko (obr. 25/1). Ide o častý krest’anský symbol, ktorý sa však v novoveku stále viac využíva ako emblém slobodomurárov. Taký nález nie je prekvapivý, ked’že vieme, že niektorí členovia rodiny Koháryovcov boli v závere 18. storočia slobodomurármi.

Skupina kovových nálezov z interiéru tretej brány sa výrazne odlišuje od nálezov z priekopy. Najviac bolo tiež železných klincov, ale predmetov d’alších kategórii bolo podstatne menej. Reprezentuje ich niekol'ko gombíkov, olovených guliek a hrotov šípov datovaných od 16. storočia. Špecifickými sú nálezy fragmentov olovených okenných rámov, ktoré nám umožňujú rekonštrukciu okien brány v období záveru stredoveku. Najkrajším nálezom z interiéru brány bol kvalitný bronzový kohútik zo suda so zachovanými známkami výrobcu (obr. 25/3). 

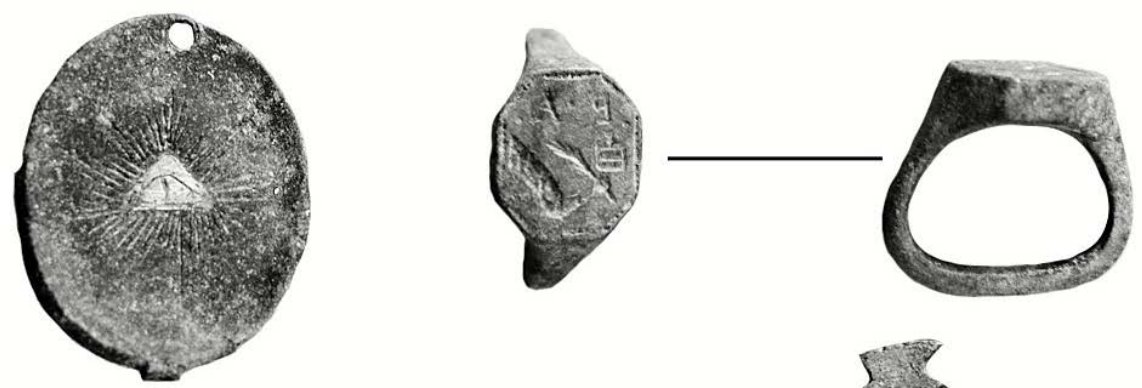

$\mathrm{Cm}$

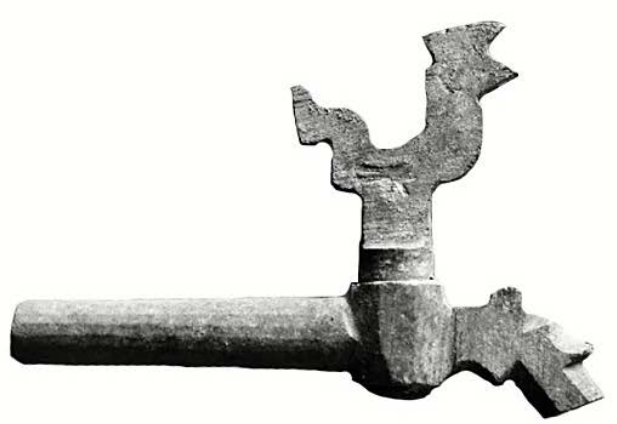

Obr. 25. Hrad Čabrad', okr. Krupina. Výber drobných nálezov z výskumu v rokoch 2013-2015. Foto M. Mordovin. Abb. 25. Burg Čabrad', Bezirk Krupina. Auswahl an Kleinfunden von der Grabung 2013-2015. Foto M. Mordovin.

V sekundárnej polohe bola nájdená olovená plomba, ktorá je jedným z najkrajších nálezov tohto typu z územia Slovenska (obr. 26/2). Ide o mimoriadne kvalitnú obchodnú známku anglickej tkaniny. Na jednej strane má vyobrazený anglický erb z prvej polovice 16. storočia a na druhej tzv. Tudorskú ružu. Podl'a analógií je dobre datovatel'ná do obdobia vlády Henricha VIII. Nález tejto plomby a opavskej známky objavenej v priekope (obr. 26/1) dokladá dôležité dial'kové kontakty majitel’ov hradu v závere stredoveku. Hrad Čabrad'sa nálezmi olovených plomb stal jednou z najdôležitejších lokalít na Slovensku (Hunka 1999). Počas troch rokov výskumu sa ich objavilo niekol'ko (viedenská, anglická, opavská plomba a niekol'ko neurčitel'ných). Z výskumu priekopy pred tret'ou bránou pochádza aj 20 nálezov mincí (napr. z rokov 1670, 1696, 1699, 1700, 1707, 1708, 1762, 1763, 1781 a 1782), ktoré nám napomohli datovat' jej
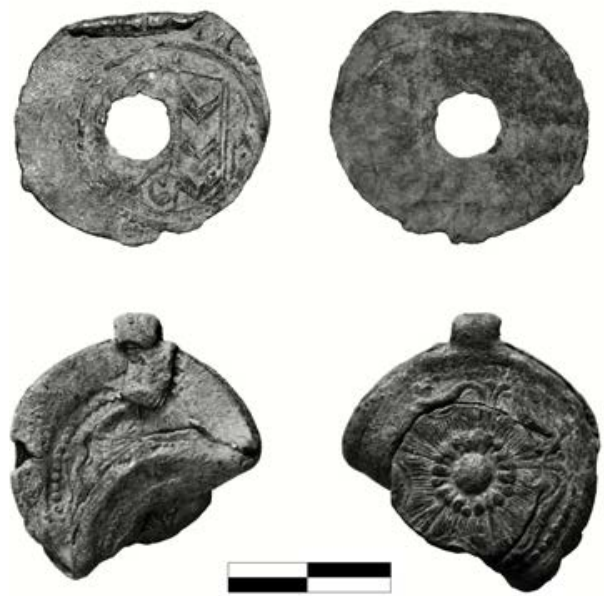

Obr. 26. Hrad Čabrad', okr. Krupina. Výber drobných nálezov z výskumu v rokoch 2013-2015. Foto M. Mordovin. Abb. 26. Burg Čabrad', Bezirk Krupina. Auswahl an Kleinfunden von der Grabung 2013-2015. Foto M. Mordovin. jednotlivé vrstvy.

\section{Datovanie vzniku tretej brány a nové poznatky k stavebnému vývoju hradu}

Výskum tretej brány priniesol nové poznatky k stavebnému vývoju hradu a jeho podobe v 16. storočí. Budova tzv. tretej hradnej brány (v dobových prameňoch hornej) je jednou z kl’účových stavieb renesančného opevnenia hradu Čabrad', vybudovaného v priebehu 16. storočia. Jej predchodcom bola stredoveká brána susediaca s baštou, v ktorej bola v roku 1476 umiest- 
nená vyhňa a stajne. Tieto stredoveké stavby zatial' nevieme v rámci hradného areálu presne lokalizovat'. Po deštrukcii objektov, azda po vydobytí hradu, došlo po roku 1549 k rozsiahlej obnove hradu spojenej s vybudovaním novej bránovej budovy. Rozsah stavebných prác naznačujú písomné pramene. Podl’a nich stavebné úpravy na Čabradi spolu s prácami na hrade Sitno v roku 1558 dosahovali výšku 2000 zlatých (v nasledujúcich rokoch ešte narastali), pričom práce koordinoval taliansky stavitel' Francesco de Pozzo (Maliniak-Nagy 2013, 109, 163, 170). Datovanie vzniku brány do obdobia okolo roku 1550 potvrdzuje inventár hradu z roku 1558, kde zmienka o zbraniach pod bránou jasne odkazuje na stojacu stavbu brány s obranným suterénom. V súlade s týmto datovaním vzniku brány je jej zachovaná architektúra, ako aj tvaroslovné a fortifikačné prvky, ktoré majú svoje analógie z obdobia okolo polovice 16. storočia. Zvyšok portálu do prevétu s plytkou esovitou profiláciou patrí medzi bežné profilácie okien a portálov z druhej polovice 16. a začiatku 17. storočia. Medzi dobre datované rané príklady využitia tejto profilácie patria okná na veži hradu Budatín, kde je na jednom z okien letopočet 1551. S týmto obdobím korešponduje aj podoba komorových striel'ní spodného podlažia. Takmer identické komorové delové striel’ne sú zachované na baštách hradov Červený Kameň (vznik okolo roku 1540, Menclová-Štech 1954, 15-20; Bóna-Šimkovic 2009, 266), Plavecký hrad a Branč (vystavané okolo roku 1550, Šimkovic 2008, 9; 2011, 26). Účastou talianskeho stavitel’a Francesca de Pozzo je možné vysvetlit' vyspelú architektúru brány s vel'kým počtom striel'ní, masívnymi šikmými soklami ukončenými oblou rímsou a padacím mostom vahadlovej konštrukcie. Vysvetlenie náročných obytných priestorov $\mathrm{v}$ hornom podlaží brány ponúkajú písomné pramene. Hradné inventáre zo 16.-17. storočia naznačujú, že v bráne sídlil kapitán. V jej pivničných priestoroch sa azda nachádzala zbrojnica.

Brána stojí na počiatku rozsiahlych prác na opevnení hradu. Na krátky čas (približne jedno desat'ročie) zrejme predstavovala nový vstup do hradu. S pomerne krátkym odstupom sa na ňu napojilo opevnenie rozsiahleho priestoru vonkajšieho predhradia, obklopujúceho starší hrad z južnej, východnej a západnej strany. Severná čast' nového opevnenia predhradia vo forme parkánu obchádza staršie opevnenie a prechádza aj pozdíž východnej strany skúmanej bránovej stavby. Výstavba tohto úseku si vyžiadala navýšenie terénu, čím sa strielne spodného podlažia dostali do nefunkčnej polohy a boli zamurované. Rozsiahle opevnenie predhradia sa javí ako jednotné dielo. Jeho výstavbu je možné dat' do súvisu s písomnými zmienkami o stavebných prácach z roku 1561, ked' boli na hrade postavené drevené stajne pre 40 koní a bašta s klenbou.

Uvedené úvahy o datovaní potvrdzuje pôdorys a axonometrická kresba hradu od Nicola Angieliniho z rokov 1572-1573 (obr. 8), ktorá zachytáva plne sformované opevnenie predhradia. Hrad mal v tejto dobe výrazne pevnostný charakter takmer bez obytných budov. V hornom hrade je ústrednou obytnou stavbou prestavaná stredoveká obytná veža. D̆alšou budovou s obytnými priestormi bola práve skúmaná bránová stavba, ktorá popri ochrane vstupu mohla plnit' funkciu jednej z hlavných obytných budov. To potvrdzujú aj výskumom získané archeologické nálezy. Podl'a analýzy súboru keramiky je zrejmé, že sú tu zastúpené predovšetkým luxusné druhy keramiky. Reprezentujú ich napríklad bohato zdobené (kukučkou alebo mal'ovaním) misy a taniere, ale aj rôzne tvary habánskej keramiky. Je tu tiež zastúpená kvalitná keramika vyrobená z bielych ílov z územia Gemeru a Novohradu. Jednoduchšie tvary kuchynskej keramiky majú analógie $\mathrm{v}$ blízkom regióne Novohrad, Tekov i samotnom Honte. K vzácnejším nálezom patria strieborné pracky, zlatý drôtik a bronzové prstene. Vzácnu skupinu predmetov z farebných kovov tvoria pútnické známky. Objavená bola aj mimoriadne kvalitná obchodná známka anglickej tkaniny. Na jednej strane má vyobrazený anglický erb z prvej polovice 16. storočia a na druhej tzv. Tudorskú ružu. Podl'a analógií je dobre datovatel'ná do obdobia vlády Henricha VIII. Takéto nálezy dokladajú dial'kové kontakty majitel'ov hradu v závere stredoveku. $Z$ výskumu priekopy pred tret'ou bránou hradu Čabrad' pochádza aj 20 nálezov mincí (napr. z rokov 1670, 1696, 1699, $1700,1707,1708,1762,1763,1781$ a 1782), ktoré nám pomohli datovat' jednotlivé vrstvy a spresnit' chronológiu keramických nálezov v tomto regióne. 
Príspevok je publikovaný v rámci riešenia projektu Vedeckej grantovej agentúry Ministerstva školstva, vedy, výskumu a športu Slovenskej republiky a Slovenskej akadémie vied (VEGA) číslo 1/0208/15: Človek a hory v priebehu času - od pravekých hradísk k stredovekým hradom a v rámci projektu APVV-0051-12: Stredoveké hrady na Slovensku. Život, kultúra, spoločnost’ a Centra excelentnosti SAV: Hrady na Slovensku. Interdisciplinárny prierezový pohlad na fenomén hradov. Analýza keramických nálezov bola vypracovaná s podporou štipendia Jánosa Bolyaia.

\section{Pramene a literatúra}

BAKÁCS, I., 1971: Hont vármegye Mohács elött. Budapest.

BALASSA CS. LT. 1990: A Balassa család levéltára 1193-1526 (Fekete Nagy, A.-Borsa, I., edd.). Budapest. BAXA, P., 1978: Výskumy a nálezy v historickom jadre Bratislavy. In: AVANS 1978, 39-42. Nitra.

BELJAK, J.-ČURNÝ, M.-PAŽINOVÁ, N., 2008: Novoveká keramika z lesných bystrín v Sucháni, Studia Historica Nitriensia 14, 31-41.

BENDA, J., 2007: Fazekasmühely a 18. századi Vízivárosban - Eine Töpferwerkstatt in der budaer Wasserstadt des 18. Jahrhunderts, Budapest Régiségei 40, 295-311.

BERTALAN, V., 1998: XV-XVII. századi díszedények Óbudáról, Budapest Régiségei 32, 211-243.

BIELICH, M.-ČURNÝ, M., 2009: Pipe finds from Nitra pipe production, Studies in Post-Medieval Archaeology 3. Post Medieval Ceramics. Production, assortment, usage, 337-362.

BÓNA, M.-ŠIMKOVIC, M., 2009: Fortfikačná architektúra. In: Rusina, I. a kol., Renesancia. Dejiny výtvarného umenia Slovenska, 264-271. Bratislava.

BOROVSZKY, S., szerk., [1906]: Magyarország vármegyéi és városai. Hont vármegye és Selmeczbánya. Budapest.

CDH: Codex diplomaticus Hungariae ecclesiasticus ac civilis I.-XI (Fejér, G., ed.). Budae 1828-1844.

ČURNÝ, M., 2004: Keramika zo 16.-18. stor. na juhozápadnom Slovensku na príklade nálezov z kaštiela v Lukáčovciach. Diplomová práca na UKF v Nitre.

ČURNÝ, M.-KOPČEKOVÁ, M., 2001: Záchranný archeologický výskum v Boroviciach. In: AVANS 2001, 39. Nitra.

ČURNÝ, M.-PAŽINOVÁ, N., 2010: Výbava meštianskej domácnosti v novovekom Komárne. In: Klára Kuzmová-Ján Rajtár (zost.): Rímsky kastel v Iži. Výskum 1978-2008. Archaeologica Slovaca Monographiae. Communicationes. Tomus XII., 145-158. Nitra.

ČURNÝ, M.-ŠIMČÍK, P.-BIELICH, M., 2013: Nálezy keramických fajok z archeologických výskumov a prospekcií na Slovensku I., ŠZ AÚ SAV 53, 85-101.

DL: Magyar Nemzeti Levéltár - Országos Levéltár Budapest, fond Diplomatikai levéltár.

GYÖRFFY, Gy., 1987: Az Árpád-kori Magyarország történeti földrajza III. Budapest.

HANULIAK, V., 2004: Hrad Čabrad'v dejinách Hontu - Burg Čabrad' in der Geschichte von Hont, AH 29, 299-308.

HARL, O., red., b. r.: Keramische Bodenfunde aus Wien. Mittelalter - Neuzeit. Wien.

HAVASSY, P., 2003: Fuvarosok és szekeresek a hajdani Gömör vármegyében. In: Vándorutak - Múzeumi örökség. Tanulmányok Bodó Sándor tiszteletére, 60. születésnapja alkalmából. Red.: Gyula Viga - Szilvia Andrea Holló - Edit Cs. Schwalm, 421-428. Budapest.

HM HB: Slovenský národný archív v Bratislave, fond Hodnoverné miesto konventu benediktínov v Hronskom Beňadiku.

HORVÁTH, R., 2011: Itineraria regis Matthiae Corvini et reginae Beatricis de Aragonia (1458-[1476]-1490). Budapest.

HUNKA, J., 1999: Nálezy olovených plômb na zaistovanie prepravovaných tovarov (14.-17. stor.) zo Slovenska, ŠZ AÚ SAV 33, 295-308.

KALMÁR, J., 1959: A füleki (Filakovo) vár XV-XVII. századi emlékei. Budapest.

KISARI BALLA, Gy., 1996: Törökkori várrajzok Stockholmban. Budapest.

- 1998: Száz várrajz Württembergben - Hundert Festungspläne in Württemberg. Budapest.

- 2000: Karlsruhei térképek a török háborúk korából - Kriegskarten und Pläne aus der Türkenzeit in der Karlsruher Sammlungen. Budapest.

KOTOROVÁ-JENČOVÁ, M., 2006: Výskum Stropkovského hradu. In: AVANS 2006, 95-97. Nitra.

KOVÁCS, Gy., 2002: Weitschawar / Bajcsa-vár. Egy stájer erődítmény Magyarországon a 16. század második felében. Zalaegerszeg.

KOVÁCSOVÁ, E., 2004: Záchranné výskumy na území mesta Nové Zámky. In: AVANS 2004, 116-118. Nitra.

KUBÍN, P., 2004: Zpráva o záchranném archeologickém výzkumu na Brněnské ulici v Mikulově, Sborník Regionálního muzea v Mikulově, 87-102. 
MALINIAK, P., 2016: Stavebné a funkčné členenie hradu Čabrad' na základe inventárov do začiatku 17. storočia. In: Za Boha, král’a a vlast'! Koháryovci v uhorských dejinách. Zborník z odborného seminára. Múzeum v Svätom Antone, v tlači.

MALINIAK, P.-NAGY, I., edd., 2013: Turek na obzore. Z prameňov k uhorsko-osmanským vzt’ahom. Kraków. MENCLOVÁ, D.-ŠTECH, V. V., 1954: Červený Kameň. Bratislava.

MIŇO, M., 2010: Príspevok k životu v stredovekom vojenskom tábore - Ein Beitrag zum Leben in einem mittelalterlichen Militärlager, AH 35, 81-93.

MKA: Magyar Kamara archívuma, fond Magyar kincstári levéltárak.

MNL: Magyar Nemzeti Levéltár - Országos Levéltár Budapest [Mad’arský národný archív - Krajinský archív v Budapešti].

PLAČEK, M.-BÓNA, M., 2007: Encyklopédia slovenských hradov. Bratislava.

RATKOŠ, P., 1958: Hrad Čabrad' na konci stredoveku, Pamiatky a múzeá 7, 95-96.

Ř́lHA, M., 1980: Výsledky výskumu hradu Branč v obci Podbranč. In: AVANS 1980, 260-263. Nitra.

ROGANSKÝ, L., 2006: Výskum mestského opevnenia v Krupine. In: AVANS 2006, 127-128. Nitra.

- 2007: Výskum mestského opevnenia v Krupine. In: AVANS 2007, 158-159. Nitra.

RUTTKAY, M., 2004: Polykultúrna lokalita v Nitre na Svätoplukovom námestí. In: AVANS 2004, 167-169. Nitra.

SAMUEL, M., 2005: Záchranný výskum na stavbe Business Centra na Mostnej ulici v Nitre. In: AVANS 2005, 174-176. Nitra.

- 2006: Ďalší záchranný výskum na Mostnej ulici v Nitre. In: AVANS, 138-142. Nitra.

- 2007: Archeologický výskum „Franklinovského kaštiela“"v Necpaloch. In: AVANS 2007, 168-170. Nitra.

SIKLÓSI, Gy., 2002: Egy székesfehérvári fogadó 18-19. századi üveg- és kerámiaanyaga. Budapest.

SNA: Slovenský národný archív v Bratislave.

SZÁNTÓFY, A., 1869: Bakacs Tamás végrendelete, Magyar Sion VII, 522-531.

ŠIMKOVIC, M., 2008: Plavecký hrad. Bratislava.

- 2011: Hrad Branč. Bratislava.

THALY, K., 1867: Csábrág vára (Történeti rajz), Magyarország és a Nagy Világ III, 3. sz., 25-28.

- 1867a: Csábrág vára (Vége), Magyarország és a Nagy Világ III, 4. sz., 37-40.

UetC: fond Urbaria et Conscriptiones.

VÁLINÉ POGÁNY, J., 2000: Az örökség hagyományozása. Könyöki József műemlékfelmérései 18691890. Budapest.

VIZI, M., 2010: A kora újkori kerámia feldolgozásának módszerei - Methods for the Processing of Early Modern Age Ceramics. In: A középkor és a kora újkor régészete Magyarországon - Archaeology of the Middle Ages and the Early Modern Period in Hungary. II. (Benkő, Elek-Kovács, Gyöngyi, red.), 817-838. Budapest.

ZsO I: Zsigmondkori oklevéltár I (1387-1399) (Mályusz, E., ed.). Budapest 1951.

ZsO V: Zsigmondkori oklevéltár V (1415-1416) (Mályusz, E.-Borsa, I., edd.). Budapest 1997.

\section{Zusammenfassung}

\section{Die Grabung am dritten (ursprünglich oberen) Tor der Burg Čabrad’ von 2013-2015}

Die am dritten Tor der Burg Čabrad' durchgeführte Grabung lieferte neue Erkenntnisse über die bauliche Entwicklung der Burg und ihr Aussehen im 16. Jahrhundert. Das Gebäude des sog. dritten Burgtors (in zeitgenössischen Quellen als oberes Tor bezeichnet) ist einer der Schlüsselbauten der im 16. Jahrhundert errichteten Renaissancebefestigung der Burg. Sein Vorgänger war ein mittelalterliches Tor, das neben einer Bastei stand, in welcher im Jahr 1476 eine Esse und Ställe untergebracht waren. Nach dem Jahr 1549 erfolgte ein umfangreicher Wiederaufbau der Burg, mit dem auch die Errichtung eines neuen Torgebäudes einherging. Der Umfang der Bauarbeiten wird in den schriftlichen Quellen angedeutet. Laut ihnen erreichten die Kosten der Umbauten auf Burg Čabrad' zusammen mit den auf Burg Sitno durchgeführten Arbeiten im Jahr 1558 eine Höhe von 2000 Gulden (die in den darauffolgenden Jahren noch anstiegen), wobei die Arbeiten von dem italienischen Baumeister Francesco de Pozzo koordiniert wurden (Maliniak-Nagy 2013, 109, 163, 170). Die Datierung der Entstehung des Tores in die Zeit um das Jahr 1550 wird in einem Inventar der Burg aus dem Jahr 1558 bestätigt, worin sich eine 
Erwähnung über Waffen unter dem Tor findet, die deutlich auf einen stehenden Torbau verweist, dessen Souterrain eine Wehrfunktion besaß. Die erhalten gebliebene Architektur befindet sich ebenso wie die formgebenden und Befestigungselemente im Einklang mit dieser Datierung der Entstehung des Tores. Die Beteiligung des italienischen Baumeisters Franceso des Pozzo kann als Erkläurung für die hochentwickelte Architektur des Tores mit seinen vielen Schießscharten, mit den massiven, von runden Simsen abgeschlossenen Sockeln und mit der als Wippkonstruktion angelegten Fallbrücke dienen. Eine Erklärung für die aufwändigen Wohnräume im oberen Stockwerk des Tors wird von den schriftlichen Quellen angeboten. Die Burginventare aus dem 16.-17. Jahrhundert deuten an, dass im Tor ein Hauptmann wohnte. In den Kellerräumen des Tors befand sich wohl die Rüstkammer.

Das Tor machte den Anfang zu umfangreichen Befestigungsarbeiten auf der Burg. In relativ kurzem Abstand daran schloss sich eine Befestigung des Bereichs der äußeren Vorburg an, der die ältere Burg von der Süd-, Ost- und Westseite her umgab. Der Nordteil der neuen Befestigung der Vorburg umschloss die ältere Befestigung in Form eines Zwingers und verlief auch entlang der Ostseite des untersuchten Torbaus. Der Bau dieses Abschnittes machte eine Aufschüttung des Geländes erforderlich, wodurch die Schießscharten des Untergeschosses außer Funktion gesetzt und deshalb zugemauert wurden. Die umfangreiche Befestigung der Vorburg präsentiert sich als einheitliches Werk. Ihre Errichtung kann mit den schriftlichen Erwähnungen von Bauarbeiten aus dem Jahr 1561 in Verbindung gebracht werden, als auf der Burg Holzställe für 40 Pferde und eine eingewölbte Bastei gebaut wurden.

Die hier aufgeführten Überlegungen zur Datierung werden durch den Grundriss und eine axonometrische Zeichnung von der Burg von Nicolo Angielini aus den Jahren 1572-1573 bestätigt, welche die endgültige Form der Befestigung der Vorburg wiedergeben. Das von Angielini 1572-1573 festgehaltene Aussehen der Burg ist im breiteren Kontext der Entwicklung der Burg bemerkenswert. Die Burg hatte zum damaligen Zeitpunkt einen deutlichen Festungscharakter fast ohne Wohngebäude. In der Oberen Burg stellt der zentrale Wohnbau einen umgebauten mittelalterlichen Wohnturm dar. Ein weiteres Gebäude mit Wohnräumen war der von uns untersuchte Torbau, der neben der Schutzfunktion eines Eingangs auch als eines der Hauptwohngebäude hatte dienen können. Das wird auch von den gemachten archäologischen Funden bestätigt. Aus der Analyse der Keramikkollektion wird deutlich, dass darin vor allem Luxuskeramik vertreten sind, die beispielsweise in Form von reichverzierten Schüsseln und Tellern, aber auch durch verschiedene Formen der Habaner Keramik repräsentiert wird. Ebenfalls hier vertreten ist hochwertige Keramik, die aus den weißen Tonerden der Regionen Gemer und Novohrad hergestellt wurde. Die einfacheren Formen von Küchenkeramik haben in den nahe gelegenen Regionen Novohrad, Tekov und in Hont selbst Analogien. Zu den wertvolleren Funden zählen Silberschnallen, Golddraht und Bronzeringe. Eine weitere wertvolle Gruppe von aus Buntmetall bestehenden Gegenständen bilden Pilgerzeichen. Auch wurde eine außerordentlich hochwertige Handelsmarke eines englischen Textilstoffs entdeckt, der auf der einen Seite ein englisches Wappen aus der ersten Hälfte des 16. Jahrhunderts und auf der anderen eine sog. Tudor-Rose zeigt. Anhand von Analogien lässt sich der Stoff gut in die Herrschaftszeit von Heinrich VIII. datieren. Solche Funde belegen, dass die Besitzer der Burg gegen Ende des Mittelalters Fernkontakte unterhielten. Aus der Grabung am Graben vor dem dritten Tor der Burg Čabrad' stammen auch 20 Münzfunde (z.B. aus den Jahren 1670, 1696, 1699, 1700, 1707, 1708, 1762, 1763, 1781 und 1782), die uns dabei halfen, die einzelnen Schichten zu datieren und die Chronologie der Keramikfunde in dieser Region zu präsizieren.

Der vorliegende Beitrag wurde im Rahmen des Projekts der Wissentschaftlichen Förderagentur des Ministeriums für Schulwesen, Wissenschaft, Forschung und Sport der Slowakischen Republik und der Slowakischen Akademie der Wissenschaften (VEGA) Nr. 1/0208/15: Mensch und Gebirge im Lauf der Zeit - von den urzeitlichen Burgwällen bis zu den mittelalterlichen Burgen sowie im Rahmen des Projekts APVV-0051-12: Mittelalterliche Burgen in der Slowakei. Leben, Kultur, Gesellschaft und des Excellenzzentrums der Slowakischen Akademie der Wissenschaften: Eine Interdisziplinäre Querschnittsbetrachtung der Burgen veröffentlicht. Die Analyse der Keramikfunde wurde mit der Förderung eines János-Bolyai-Stependiums ausgearbeitet. 
PhDr. Ján Beljak, PhD., Archeologický ústav SAV, Vysunuté pracovisko Zvolen, Štúrova 2, SK 96053 Zvolen, Slovenská republika, beljak@savzv.sk

PhDr. Pavol Maliniak, PhD., Katedra histórie Filozofickej fakulty Univerzity Mateja Bela, Tajovského 40, SK 97401 Banská Bystrica, Slovenská republika, pavol.maliniak@umb.sk

Dr. Maxim Mordovin, ELTE BTK Régészettudományi Intézet, Múzeum krt. 4/B, 1088 Budapest, Mad'arsko,mordovin.maxim@btk.elte.hu

Mgr. Michal Šimkovic, Mgr. Michal Šimkovic s.r.o., Kimovská 2341/4, SK 96001 Zvolen, Slovenská republika,simkovic.miso@gmail.com 